九州大学学術情報リポジトリ

Kyushu University Institutional Repository

\title{
Diatom sinking fluxes in the western and central Equatorial Pacific during 1999-2002 : Summary and data
}

Onodera, Jonaotaro

Center for Advanced Marine Core Research, Kochi University

Takahashi, Kozo

Department of Earth and Planetary Sciences, Graduate School of Sciences, Kyushu University

Kobayashi, Fumiko

Department of Earth and Planetary Sciences, Graduate School of Sciences, Kyushu University

Ono, Itsuro

Center for Advanced Marine Core Research, Kochi University

他

https://doi.org/10.5109/13525

出版情報: 九州大学大学院理学研究院紀要 : Series D, Earth and planetary sciences. 32 (2)， pp. 15-44, 2009-03-02. Faculty of Science, Kyushu University

バージョン :

権利関係 : 
Mem. Fac. Sci., Kyushu Univ., Ser. D, Earth \& Planet. Sci., Vol. XXXII, No. 2, pp. 15-44, March 2, 2009

\title{
Diatom sinking fluxes in the western and central Equatorial Pacific during 1999-2002: Summary and data
}

\author{
Jonaotaro Onodera $^{*}$, Kozo Takahashi ${ }^{* *}$, Fumiko Kobayashi $^{* *}$, Itsuro Ono ${ }^{* *}$ \\ and Yoichiro Katsurada ${ }^{* *}$
}

\begin{abstract}
Diatom sinking fluxes at Sites MT3-MT7 in the western Equatorial Pacific in 1999-2002 were studied in order to decipher the ecological relationships between the diatom fluxes and environmental conditions such as water temperature and salinity. As a supplement for those studies, this paper contains the compiled data tables of diatom fluxes at Sites MT3-MT7 together with an outline of major results based on the flux data. Not only total diatom fluxes but also the relative abundances of some major diatoms reflected the spacial and temporal migrations of the water masses from the Western Pacific Warm Pool (WPWP) and the Equatorial Upwelling Region (EUR). For example, the high fluxes of Thalassiosira spp., Azpeitia spp. and Asteromphalus spp. were observed in the EUR with relatively low temperature $\left(<28^{\circ} \mathrm{C}\right)$ and high salinity $(>35.1)$. The abundances of those centric taxa may be indicative of the EUR. The correlation coefficient between total diatom fluxes and total radiolarian fluxes was significantly high at all sites. The flux ratios of radiolarian/diatoms were significantly lower than the data in the subarctic Pacific, and thus the significant contribution by both diatoms and radiolarians to biogenic opal is expected.
\end{abstract}

Keywords: diatom flux, sediment trap, equatorial Pacific, WPWP, EUR

\section{Introduction}

Four year records of diatom sinking fluxes were obtained in the western and central Equatorial Pacific in 1999-2002 in order to decipher the biogeographic relationships between diatom floral fluxes and longitudinal migrations of upper water masses associated with El Niño-Southern Oscillation (ENSO). In the research program "Global Carbon Cycle and Related Mapping based on Satellite Imagery" (GCMAPS), several sediment traps were deployed as one part of the project. As the results by the GCMAPS at this time, there are several publications on diatom biocoenosis and diatom fluxes in the Equatorial Pacific (Kobayashi and Takahashi, 2002; Ono et al., 2004; Takahashi et al., 2002, submitted). The diatom counting was conducted by three graduate school students, Department of Earth \& Planetary Sciences, Graduate School of Sciences, Kyushu University. However, three data sets of their count data had not yet been compiled to one entity from

Manuscript received on 30 Octber 2008; accepted on 8 December 2008

* Center for Advanced Marine Core Research, Kochi University, B200 Monobe, Nankoku, 7838502, JAPAN; jm-jo@kochi-u.ac.jp

** Department of Earth and Planetary Sciences, Graduate School of Sciences, Kyushu University, Hakozaki6-10-1, Fukuoka, 812-8581, JAPAN; kozo@geo.kyushu-u.ac.jp 
the first to the final years of sediment trap deployments. For the further research on diatom fluxes and paleoceanography employing diatom fossils, the publication of the compiled data is warranted. Therefore, we herewith present the compiled data of diatom fluxes as the supplement together with an outline of the major results.

\section{Samples and Methods}

The time-series sediment traps (type SMD26S-6000, Nichiyu-Giken Co. Ltd., Tokyo) were deployed at Sites MT3-MT7 in the western and central Equatorial Pacific from January 1999 to January 2003 (Table 1; Fig. 1). This sediment trap is cone-shaped with $0.5 \mathrm{~m}^{2}$ apertural area and 26 collecting sample bottles. The deployment, recovery, maintenance, and redeployment of sediment traps were conducted during the cruises of the R/V Mirai, Japan Agency for Marine-Earth Science and Technology (JAMSTEC). The sediment traps were deployed at two depths (approx. $1000 \mathrm{~m}$ [Shallow] and 2000-3000 $\mathrm{m}$ [Deep]) at all sites.

Table 1. Deployment summary of sediment traps at Sites MT3-MT7 from January 1999 through January 2003. The detail data for the sampled interval are tabulated in Appendix Table 1.

\begin{tabular}{|c|c|c|c|c|c|}
\hline Site & Coordinate & $\begin{array}{c}\text { Water } \\
\text { Depth } \\
(\mathrm{m})\end{array}$ & $\begin{array}{l}\text { Trap } \\
\text { Depth } \\
(\mathrm{m}) \\
\end{array}$ & $\begin{array}{c}\text { Sampled } \\
\text { Interval } \\
\text { (days) }\end{array}$ & Sampled Duration \\
\hline MT3 & $0^{\circ} 01^{\prime} \mathrm{S}, 145^{\circ} 01^{\prime} \mathrm{E}$ & 3680 & 2017 & $15 / 16 / 17$ & 5 Jan. 1999 - 24 Dec. 2002 \\
\hline MT4 & $0^{\circ} 03^{\prime} \mathrm{N}, 159^{\circ} 57^{\prime} \mathrm{E}$ & 2809 & 2030 & $15 / 16 / 17$ & 9 Jan. 1999 - 15 Jan. 2003 \\
\hline MT5 & $0^{\circ} 02^{\prime} \mathrm{S}, 174^{\circ} 56^{\prime} \mathrm{E}$ & 4821 & 3038 & $15 / 16 / 17$ & 13 Jan. 1999 - 16 Jan. 2003 \\
\hline MT6 & $0^{\circ} 01^{\prime} \mathrm{S}, 174^{\circ} 10^{\prime} \mathrm{W}$ & 5630 & 2945 & $15 / 16 / 17$ & $\begin{array}{l}17 \text { Jan. } 1999 \text { - } 1 \text { Jan. } 2001 \\
\text { 1 Feb. } 2002 \text { - } 21 \text { Jan. } 2003\end{array}$ \\
\hline MT7 & $0^{\circ} 00^{\prime}, 160^{\circ} 00^{\prime} \mathrm{W}$ & 5153 & 3095 & $15 / 16 / 17$ & 16 Jan. 2001 - 24 Jan. 2003 \\
\hline
\end{tabular}

For diatom analysis, we employed splits of 1/256-1/1024 aliquot sizes of the original trap samples. A fraction of the liquid sample was filtered through a Gelman ${ }^{\circledR}$ membrane filter $(47 \mathrm{~mm}$ diameter, $0.45 \mu \mathrm{m}$ pore size). The filtered sample was mounted on a microslide with Canada Balsam as the mounting medium. Diatoms were counted under an Olympus ${ }^{\circledR}$ LM BX-50 light microscope at 400x magnification. The diatom assemblages were investigated by identifying to species level; at least 200 specimens (in two instances lower than this value due to availability of small amount of samples; MT3 16 July-01 August 2001; 16-23 December 2002); and generally greater than 200 valves per sample were counted under the light microscope (Appendix Table 1). The resulting counts yielded estimates of daily fluxes of diatom valves (Takahashi, 1986). Relative abundances of individual diatom taxa are given as percentages of each taxon in the total diatom assemblage in each of the trap sample. Diatom identification and counting were performed by Fumiko Kobayashi for the first year samples, Itsuro Ono for the second year and Yoichiro Katsurada for the third and fourth year samples. The diatom taxonomy in this study is essentially based on the system by Hasle and Syvertsen (1997). Due to the insufficient taxonomic agreement and the handover among three investigators who proceeded the counts, the species list of minor diatoms observed in the studied samples are not always consistent throughout four years in the census. For instance, when a given investigator in charge of the counts decided not to be confident in providing species level identity of the taxa the investigator only provided the taxon-count values at a higher level than species. Therefore, these uncertain diatom species are lumped to one taxon at genus or order level. Takahashi et al. (2002) and Ono et al. (2004) suggested the significant adverse influence 
(a) La Nina period (1999-2000)

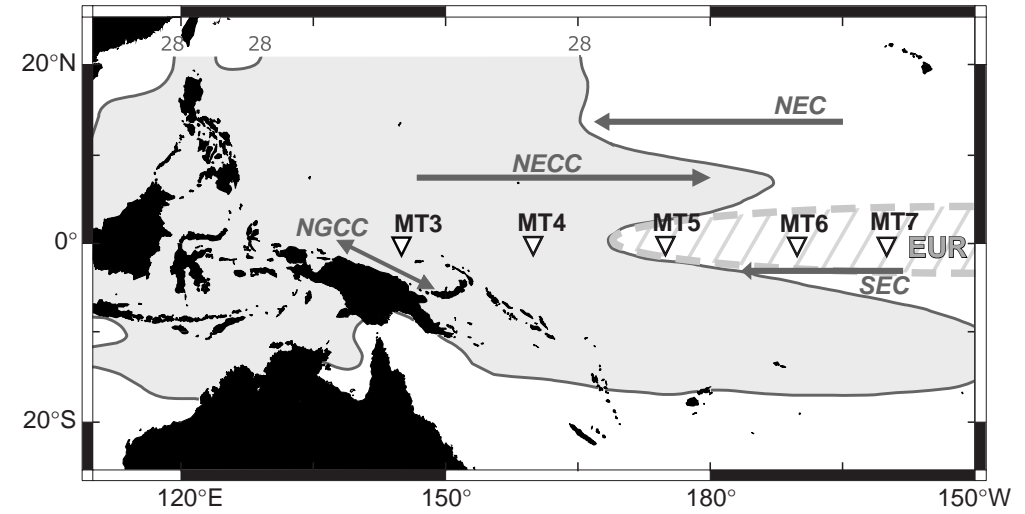

(b) El Nino period (2002)

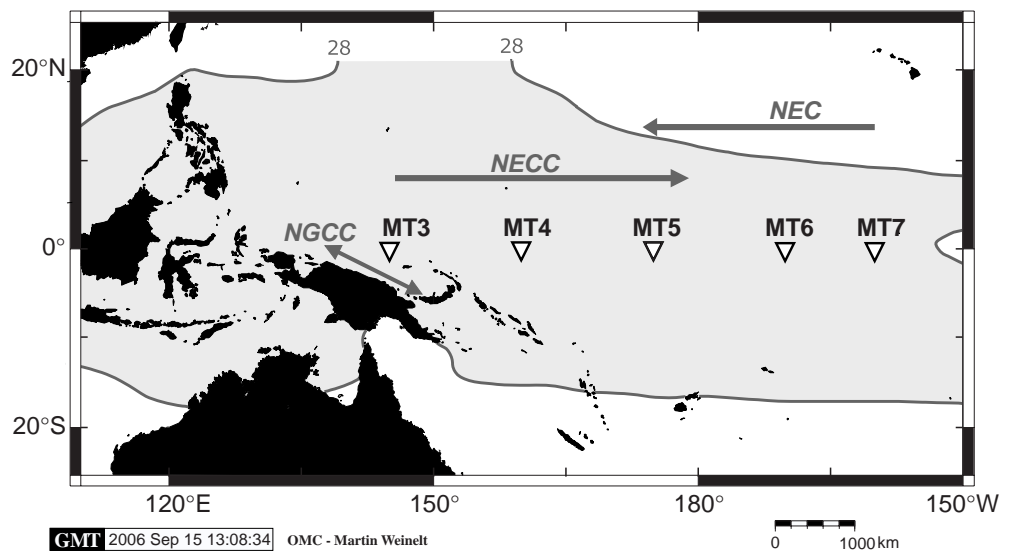

Fig. 1. The locality map of sediment trap Sites MT3-MT7 (reversed triangles) in the western and central Equatorial Pacific. The pale gray area represents the mean-high SST area $\left(>28^{\circ} \mathrm{C}\right)$ in (a) 1999 and 2000 (the La Nina condition) and (b) 2002 (the El Nino condition). EUR (hatched area): Equatorial Upwelling Region: SEC: Southern Equatorial Current: NECC: Northern Equatorial Counter Current; NGCC: New Guinea Coastal Current; and NEC: Northern Equatorial Current. SST data from Reynolds et al. (2002).

of swimmers in Shallow trap samples. Therefore, the data from Shallow sediment traps were not applied to further diatom flux study in Takahashi et al. (submitted). The data tabulated here are also limited to the data from Deep sediment traps (Appendix Tables 1-6). Although diatom photomicrographs are not presented here, the plate for major diatoms in this study is available in Ono et al. (2004).

\section{Oceanographic Setting}

In the studied area (Fig. 1), surface waters are categorized to two masses: the Western Pacific Warm Pool (WPWP); and the Equatorial Upwelling Region (EUR). The WPWP is defined by the high water temperature of greater than $28^{\circ} \mathrm{C}$ (Yan et al., 1992). The EUR is located in the east of the WPWP, which is a mild upwelling area with lower temperature of $<28^{\circ} \mathrm{C}$ (Fig. 1a). The nutrient 
supply from the subsurface into the surface layer of the WPWP is limited due to significant development of the thermocline; and thus the major nutrient concentrations and diatom standing stocks in the surface waters of the WPWP were significantly lower than those in the EUR (Kobayashi and Takahashi, 2002). During the La Nina period, Sites MT3 and MT4 were located in the WPWP whereas other sites were located in the EUR (Figs. 1a, 2a-c). During the El Nino period, the surface layers at all sites were under the influence of the WPWP waters (Figs. 1b, 2a-c). Because of the eastward migration of the WPWP in the El Nino period, the $20^{\circ} \mathrm{C}$ isotherm depths at Site MT3 in 2002 was shallower than those in the previous three years whereas those at Site MT7 in 2002 was deeper (Fig. 2d).

\section{Results and Discussion}

\subsection{Total Diatom Fluxes}

Total diatom fluxes at Sites MT3-MT7 were different depending on the years and locations (Fig. 2e). Total diatom fluxes in the WPWP area were usually lower than those in the EUR. At Site MT3 in the WPWP, total diatom fluxes in the La Nina period were essentially lower than those in the El Nino period. However, total diatom fluxes in the EUR were higher in the La Nina than in the El Nino (Fig. 2e). This spacial and temporal variation of total diatom fluxes in the studied area is essentially related to the migration of the WPWP and the EUR. The longitudinal migrations of the WPWP and the EUR water masses are consistent with the variations of SST, salinity, and $20^{\circ} \mathrm{C}$ isotherm depth (Fig. 2b-d). In particular, the biogeographic trend of total diatom fluxes was correlated at a significant level to sea surface temperature $(r=-0.58 ; \mathrm{p}<0.0001)$ and salinity $(r=$ 0.43; p<0.0001) (Fig. 3). Except for Site MT3 where lithogenic materials are partially transported from the Papua New Guinea, diatom production and flux in the studied area are significantly supported by the nutrient supply from the subsurface (Takahashi et al., submitted). The obtained correlation coefficients suggest significant contribution of subsurface waters to diatom production and their fluxes in the studied area.

\subsection{The occurrence patterns of major diatom taxa}

In a large sense, centric diatom fluxes were relatively high in the EUR whereas pennate diatom fluxes including Nitzschia bicapitata were relatively abundant in the WPWP (Fig. 4; Ono et al., 2004). The relatively high abundances of such pennate diatoms suggest their tolerances to more oligotrophic condition in the WPWP (Treppke et al., 1996; Romero et al., 1999, 2000). Among the diatom taxa occurred in this study, Rhizosolenia bergonii, Nitzschia bicapitata and genus Thalassionema were the primary component in the diatom sinking assemblages (Figs. 4-5; Takahashi et al., submitted). The secondary dominant components in the studied samples were Thalassiosira spp. (mainly composed of Thalassiosira eccentrica group, Th. endoseriata, Th. leptopus, and Th. oestrupii), Azpeitia spp. (Az. africana, Az. neocrenulata, and Az. nodulifera), and Rhizosolenia spp. (Appendix Tables 2-6). The fluxes of Nitzschia bicapitata was the highest at Site MT3 among all sites whereas Rhizosolenia bergonii flux was the highest at Site MT5 (Fig. 5). The highest fluxes of Thalassiosira spp. and Azpeitia spp. were observed at Site MT6 in 2001. Because the flux data at Site MT7 do not include the period of the La Nina, the high abundances of relatively eutrophic diatoms were recorded at Site MT6 rather than at Site MT7.

In the relationship with sea surface temperature and salinity, the mean fluxes of Nitzschia braarudii, N. bicapitata, and Rhizosolenia setigera were usually high in the condition of high temperature and low salinity (Fig. 5). Although mean fluxes of Nitzschia braarudii and N. bicapitata at Site MT7 were higher than those at Sites MT5 and MT6, this probably reflects the difference in 


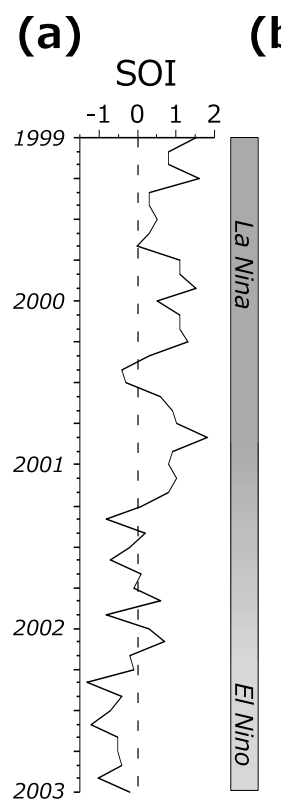

(b)

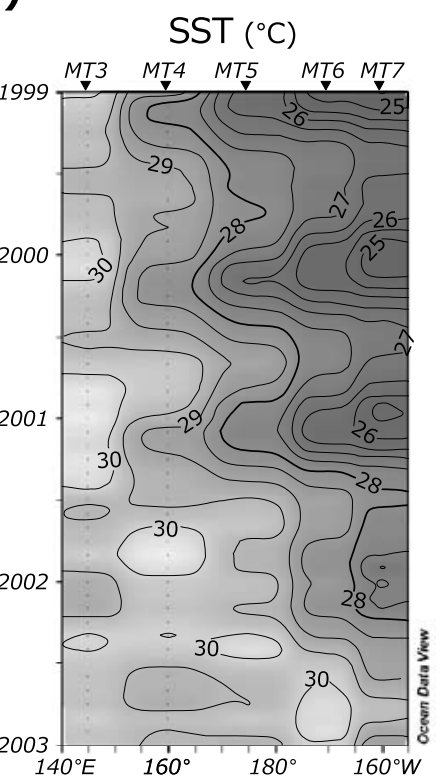

\section{(d)}
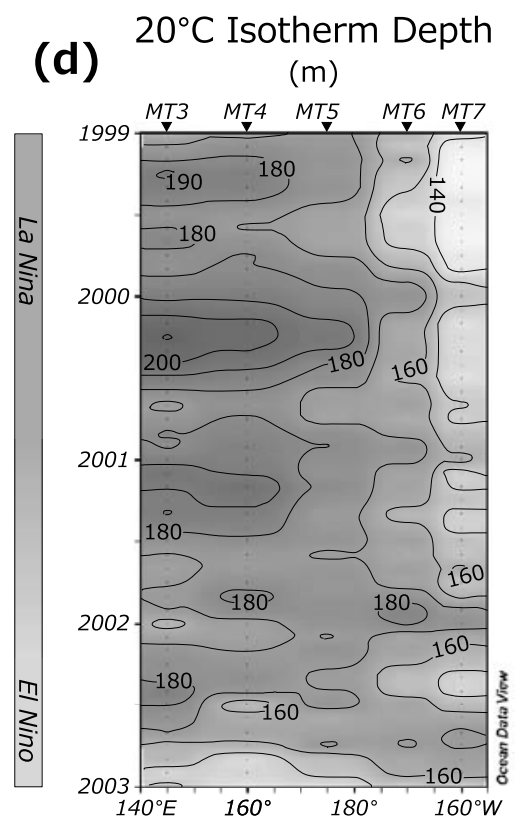

(c)

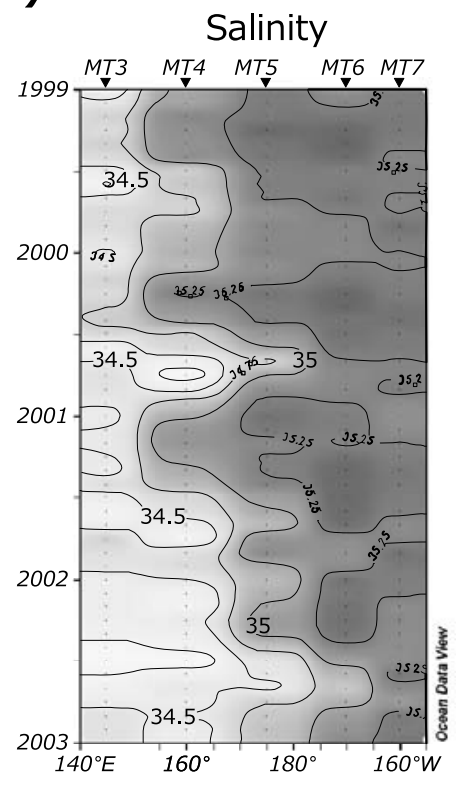

(e) Total Diatom Fluxes

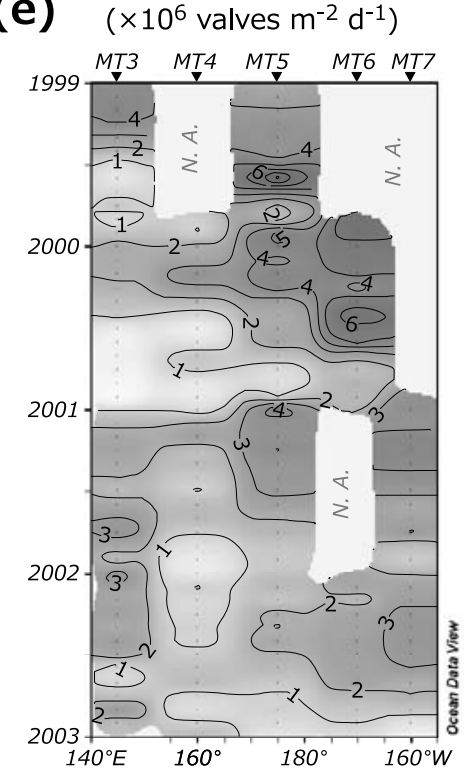

Fig. 2. Monthly isograms of (a) sea surface temperature (Reynolds et al., 2002), (b) salinity at $5 \mathrm{~m}$ water depth (Carton and Giese, submitted), (c) $20^{\circ} \mathrm{C}$ isotherm depth (Behringer et al., 1998), and (d) total diatom flux.

the sampled period; and the data at Site MT7 reflect only temporal influence of the WPWP during the El Nino. In general, Rhizosolenia setigera is common in the estuaries of temperate and subtropical regions (Takano, 1990). The limited occurrences of Rh. setigera at Sites MT3 and MT4 

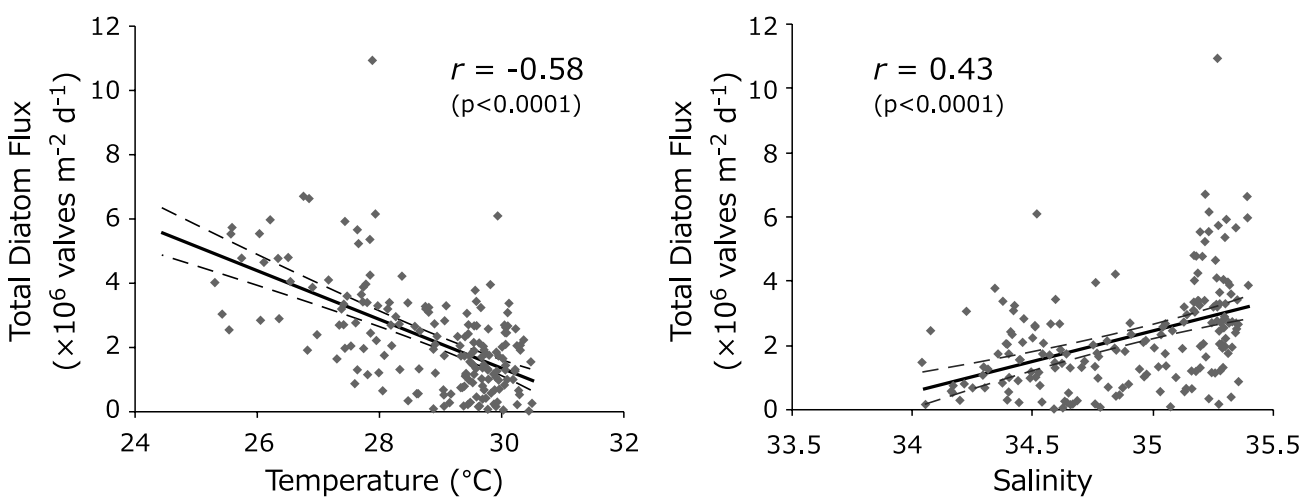

Fig. 3. The relationships between monthly data for total diatom fluxes and sea surface temperature or salinity. (a) sea surface temperature versus total diatom flux; (b) salinity versus total diatom flux. The data for SST and salinity were compared to the diatom flux in one month later, taking into account for the time lag of particle settling from sea surface to the trap depth.

probably reflect the partial influences of intensified rain fall in the western ITCZ and the Papua New Guinea during the La Nina period. The minor fluxes of Diploneis spp. were sometimes recorded at Site MT3 (Appendix Table 2). However, the Diploneis occurrences are probably explained as the advection of resuspended particles around the coasts of Papua New Guinea by the intensified undercurrent during the El Nino (Takahashi et al., submitted). The direct influences of river or coastal water input to diatom fluxes at Site MT3 are probably minor because (1) the occurrences of Diploneis were not limited to the rainy season and (2) other littoral diatoms were not recorded.

The frequencies of high flux records of Azpeitia and Thalassiosira sharply increased in condition of lower temperature $\left(<28^{\circ} \mathrm{C}\right)$ and higher salinity $(>35.1)$, which reflects the water condition of the EUR rather than the WPWP (Fig. 5). Although Rhizosolenia bergonii and Roperia tesselata also showed relatively high fluxes in the EUR than the WPWP, the responses of these taxa to temperature and salinity were rather gradual than those of Azpeitia and Thalassiosira spp. (Fig. 5). However, not only Azpeitia and Thalassiosira fluxes but also most of diatom taxon flux showed similar trends to the temporal patterns of temperature and salinity changes. Therefore, the relative abundances (percentages) of secondary dominant taxa do not show the longitudinal differences (Figs. 4-5). The biogeographic trends of diatom fluxes with different temperature and salinity conditions include the information of geographic differences on the nutrient concentrations between the WPWP (relatively oligotrophic) and the EUR (relatively eutrophic). It is not attempted at this time to determine which factor among temperature, salinity, or nutrients most significantly influenced to their flux variations. However, the biogeographic patterns of diatom fluxes are at least available for future paleoceanographic reconstruction effort as the proxy to assess which water masses of the WPWP and the EUR influenced the surface layer in the studied area.

\subsection{The relationships with radiolarian fluxes}

The radiolarian fluxes in the studied materials are the secondary component of siliceous shells in numbers of skeletons or valves. Radiolarians represent protozoa plankton whereas diatoms represent one of the major primary producer groups. And thus total radiolarian fluxes (Okazaki et al., 2008) shows the significant and positive correlation coefficient to total diatom fluxes $(r=0.68 ; \mathrm{p}<0.0001$; $\mathrm{N}=142$ ). In particular, when high total diatom flux was observed at Site MT5, the fluxes of surface radiolarian dwellers accompanied with high chlorophyll-a concentration were also high (Okazaki et 
(a)

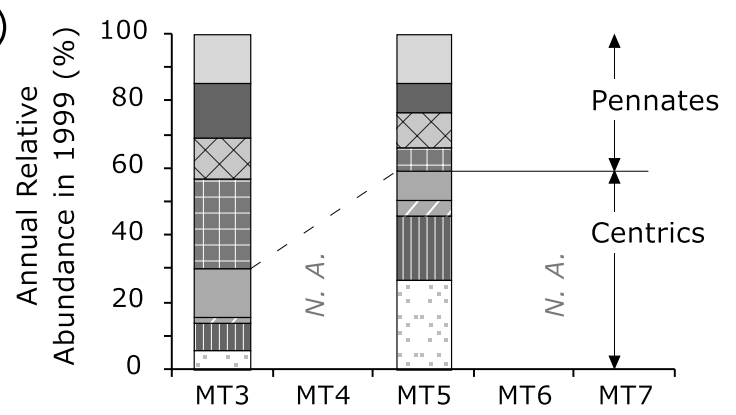

(b)

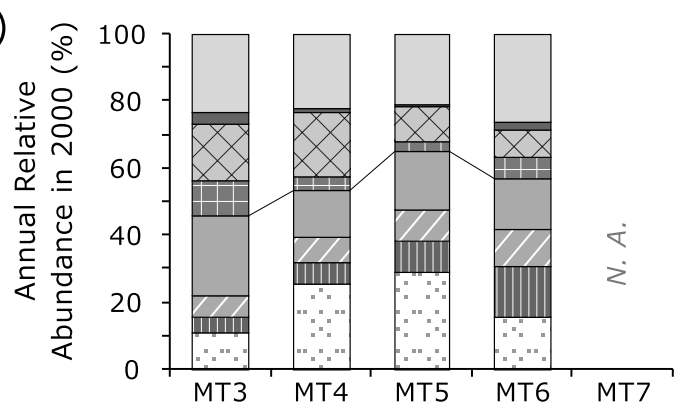

(c)

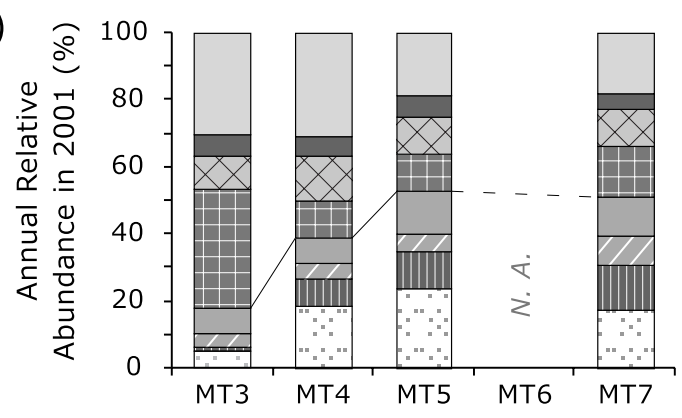

(d)

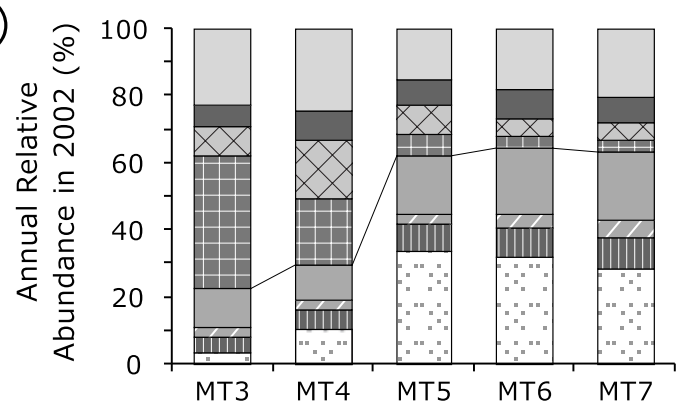

Fig. 4. Annual means of relative abundances of major diatom taxa. (a): 1999; (b) 2000; (c): 2001; and (d): 2002 . "N. A." represents "Not Available" due to no deployment or malfunctions of sediment traps. 


\section{Total Azpeitia}
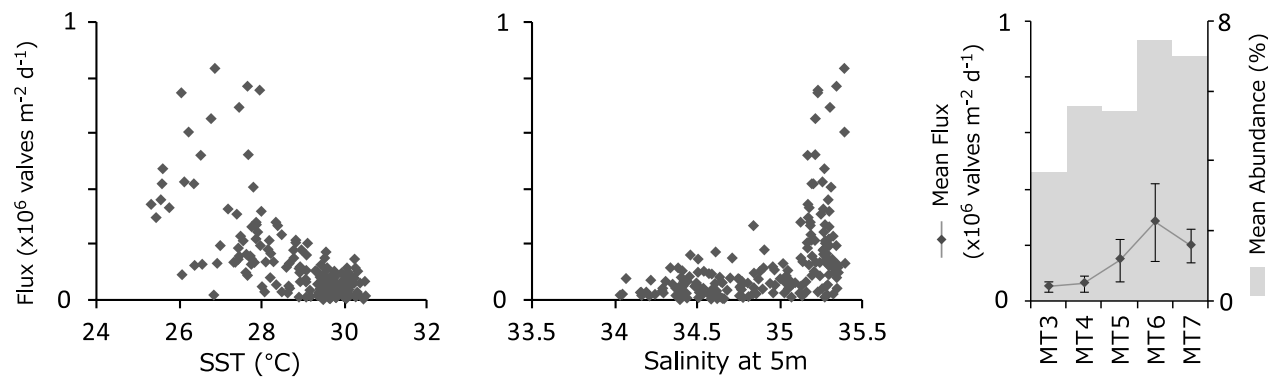

\section{Total Asteromphalus}
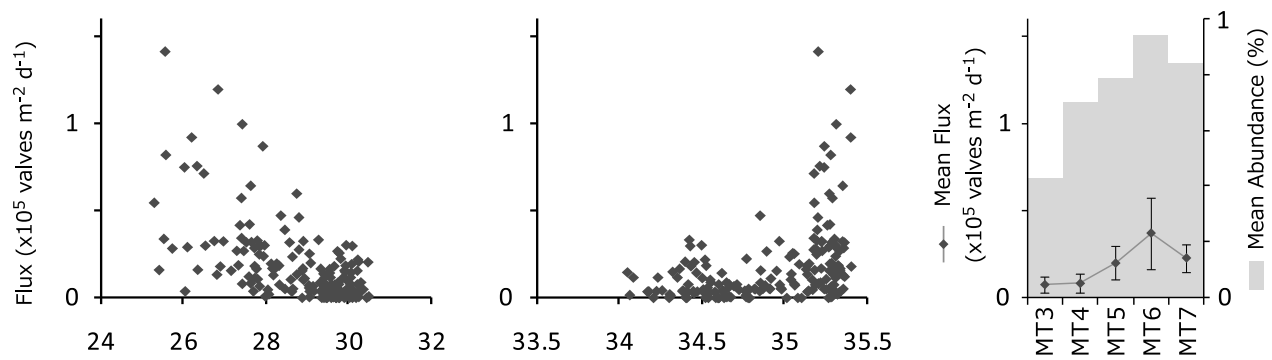

Total Thalassiosira
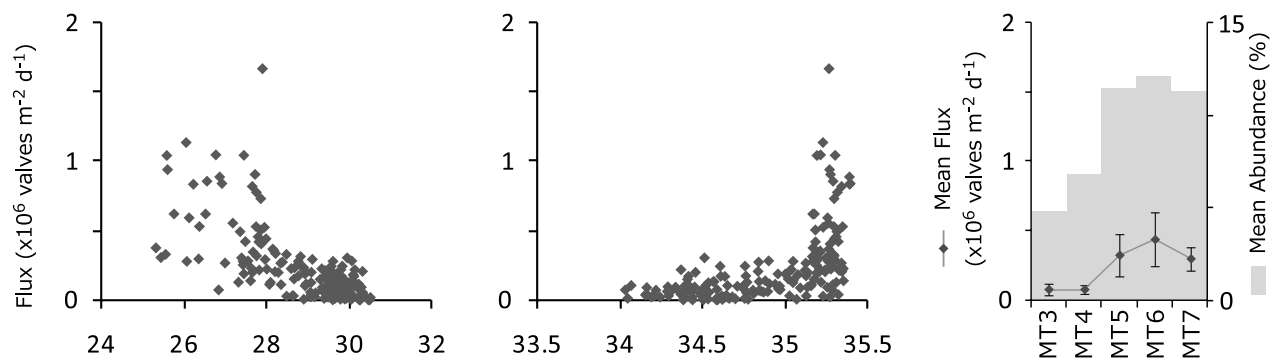

\section{Fragilariopsis doliolus}
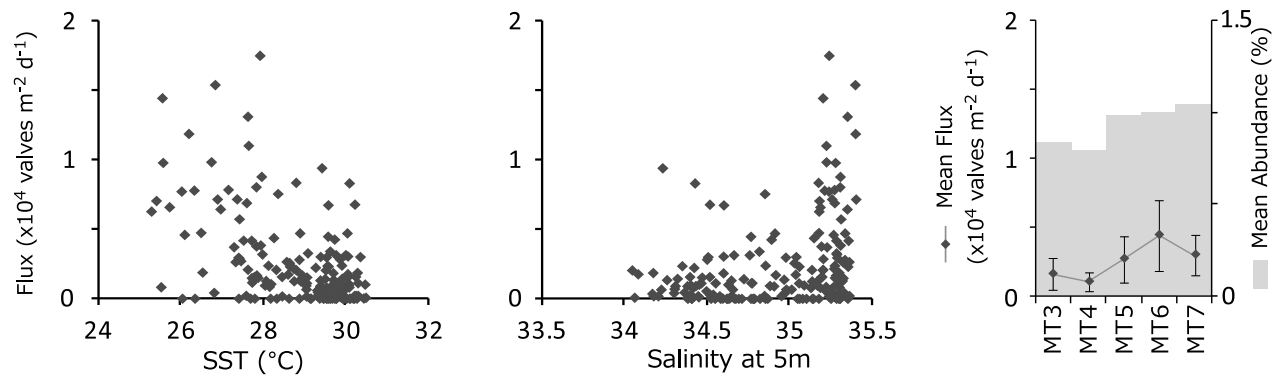

Fig. 5. The relationships between major diatom flux and sea surface temperature or salinity, and the mean flux and relative abundance at each site throughout the sampled duration. The left side: sea surface temperature versus monthly flux of diatom taxon; central: salinity at $5 \mathrm{~m}$ water depth versus monthly flux of diatom taxon; and the right side: the mean diatom flux with one standard deviation and mean relative abundance throughout the sampled duration at each site. The monthly data of SST and salinity were compared to the monthly diatom flux occurred one month later, taking into account for the time lag of particle settling from sea surface to the trap depth. 


\section{Total Actinocyclus}
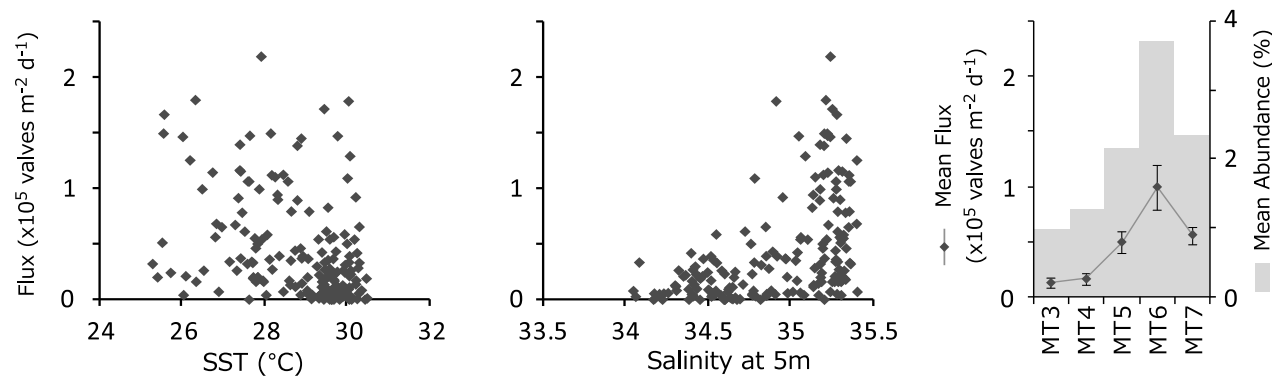

Roperia tesselata
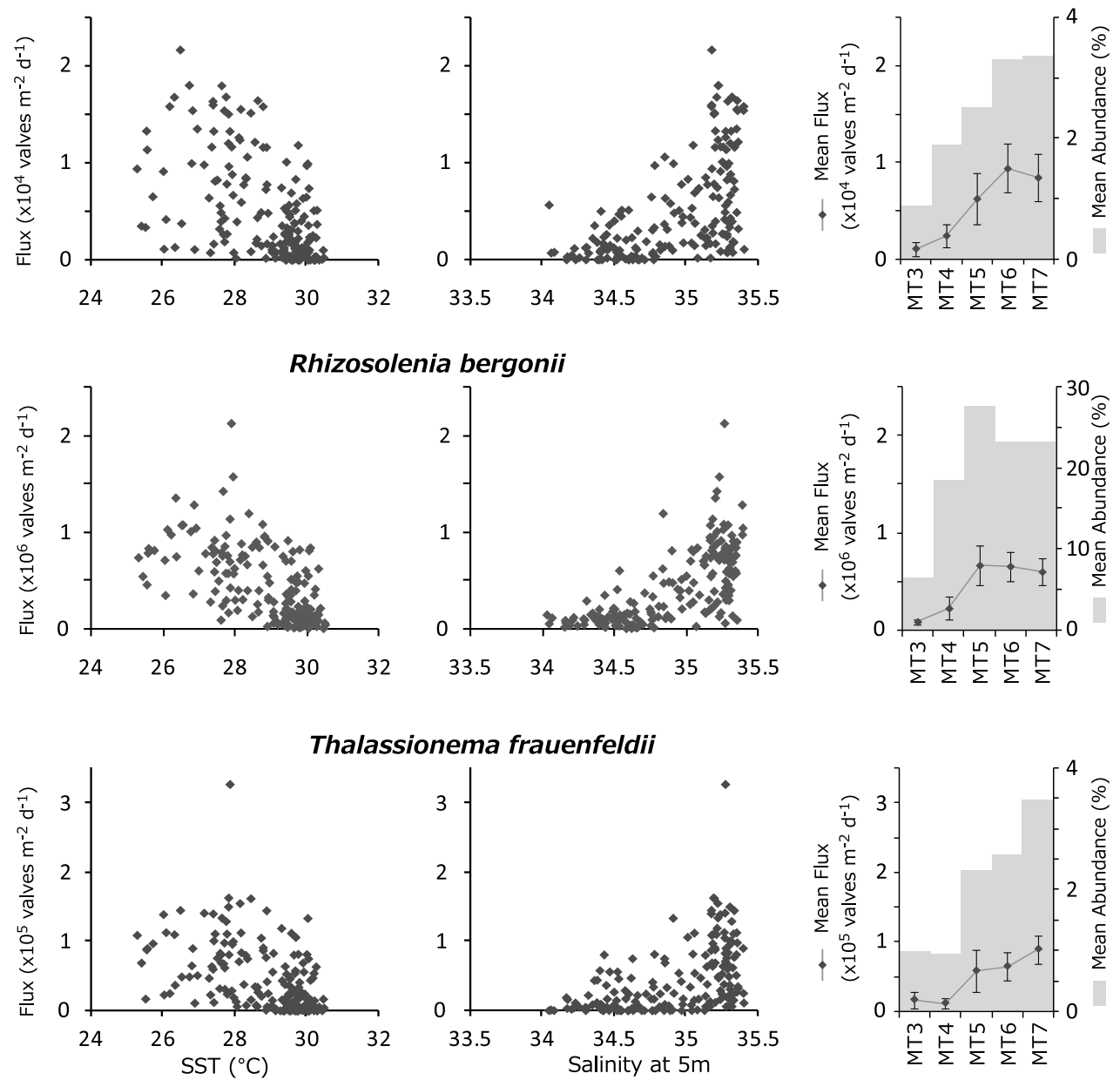

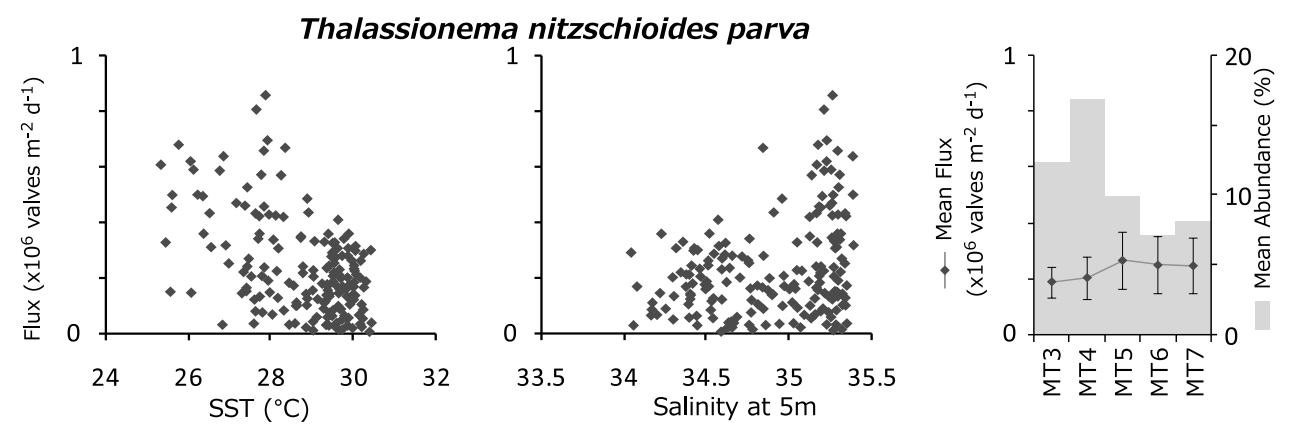

Nitzschia braarudii ?
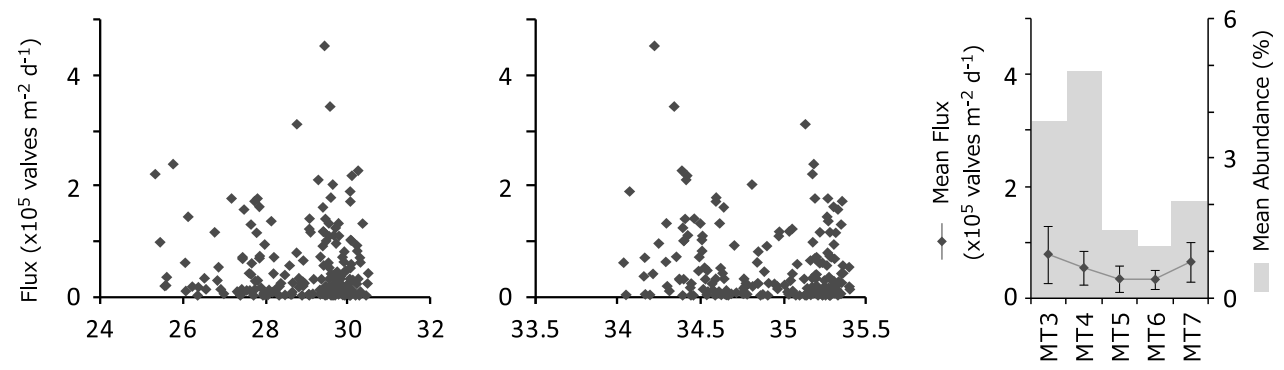

\section{Nitzschia bicapitata}
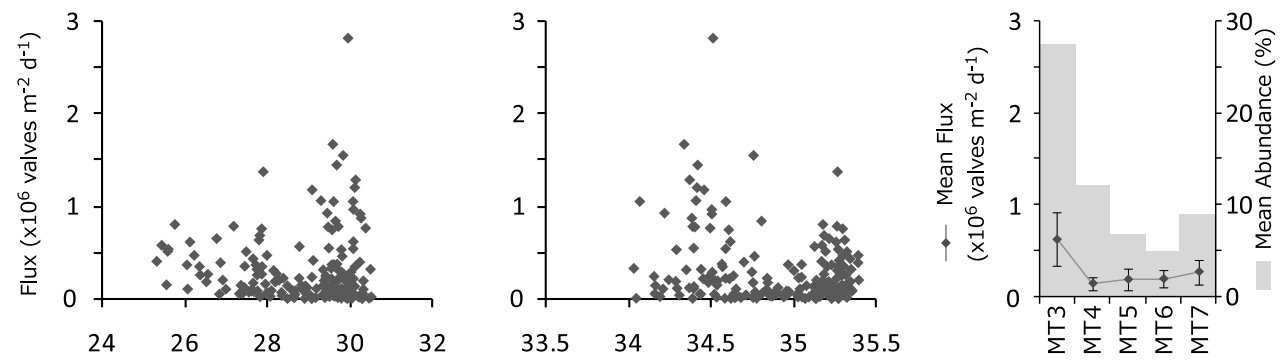

Rhizosolenia setigera
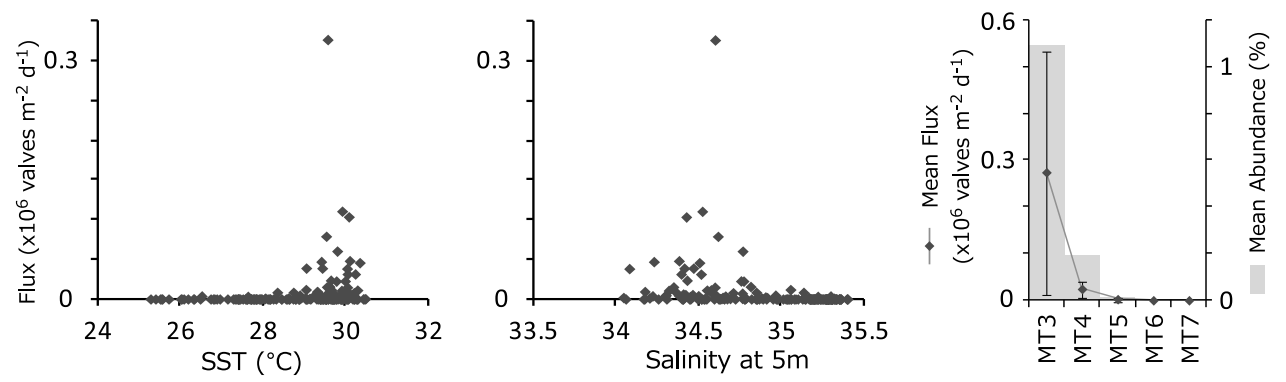

Fig. 5. (Continued) 
al., 2008; Takahashi et al., submitted). The mean total diatom fluxes during the sampled duration varied from $1.3 \times 10^{6}$ valves $\mathrm{m}^{-2} \mathrm{~d}^{-1}$ at Site MT4 to $3.3 \times 10^{6}$ valves $\mathrm{m}^{-2} \mathrm{~d}^{-1}$ at Site MT6. The mean radiolarian fluxes during the sampled duration fluctuated from $7.6 \times 10^{3}$ shells $\mathrm{m}^{-2} \mathrm{~d}^{-1}$ at Site MT3 to $23.8 \times 10^{3}$ shells $\mathrm{m}^{-2} \mathrm{~d}^{-1}$ at Site MT6 (Okazaki et al., 2008). The amplitude of total radiolarian fluxes was lower than those of diatoms. The mean flux ratio of total diatoms/total radiolarians throughout the sampled duration varied from 130 at Site MT4 to 243 at Site MT3. Therefore, the fluctuation of this ratio is primarily due to the variations of diatom fluxes. The obtained flux ratios of total diatoms/total radiolarians were significantly lower than those in the subarctic Pacific (795 at Station SA; 1215 at Station AB: Onodera and Takahashi, 2009). Although the main contributor on the weight of sinking particles is coccoliths in the studied area (Honjo et al., 2008), the importance of radiolarians as the weight of sinking particles is apparently relatively significant than in their contribution in the subarctic Pacific. This is because that the individual weights of radiolarian skeletons are several orders of magnitude greater than those of diatom frustules (Takahashi and Honjo, 1983: Conley et al., 1989). Because the primary scope of this paper is to compile the diatom flux data, a possible discussion on the respective contributions to biogenic opal is outside of the scope of this paper. However, further discussions related this theme is warranted with the biogenic opal flux data in the future studies.

\section{Acknowledgements}

We thank Prof. Hodaka Kawahata of the ORI, Tokyo University for leading the GCMAPS Project and the scientists participated in the project for discussions. We thank the captain, crew, and scientists on board R/V Mirai of JAMSTEC for their efforts of the recoveries of sediment trap samples used in this study. Dr. Kaoru Kashima of the Kyushu University, who reviewed this manuscript, is gratefully appreciated. This study was supported by the following research programs: GCMAPS promoted by the Science and Technology Agency of Japan; MEXT Grants-in-Aid-for Scientific Research B2 Project No. 15310001 and JSPS B Project No. 17310009.

\section{References}

Behringer, D.W., Ji, M., and Leetmaa, A. (1998) An improved coupled model for ENSO prediction and implications for ocean initialization. Part I: The ocean data assimilation system. Monthly Weather Review, 126, 1013-1021. WWW page: http:/ingrid.ldgo.columbia.edu/ SOURCES/. NOAA/.NCEP/.EMC/.CMB/.Pacific/.monthly/.D20eq/

Carton, J.A., and Giese, B.S. (submitted). A reanalysis of ocean climate using SODA. Monthly Weather Review. WWW page: http://iridl.ldeo.columbia.edu/SOURCES/.CARTON-GIESE/

Conley, D.J., Kilham, S.S., and Theriot, E. (1989) Differences in silica content between marine and freshwater diatoms. Limnology and Oceanography. 34, 205-213.

Hasle, G.R., and Syvertsen, E.E. (1997) Marine Diatoms. In: Tomas, C. R. (Ed.), Identifying Marine Phytoplankton. Academic Press, San Diego. pp. 5-385.

Honjo, S., Manganini, S.J., Krishfield, R.A., and Francois, R. (2008) Particulate organic carbon fluxes to the ocean interior and factors controlling the biological pump: A synthesis of global sediment trap programs since 1983. Progress in Oceanography, 76, 217-285.

Kobayashi, F., and Takahashi, K. (2002) Distribution of diatom along the Equatorial transect in the western central Pacific during the 1999 La Niña condition. Deep-Sea Research II, 49, 28012821. 
Okazaki, Y., Takahashi, K., Asahi, H. (2008) Temporal fluxes of radiolarians in the central and western equatorial Pacific. Micropaleontology, 54, 71-86.

Ono, I., Takahashi, K., and Kobayashi, F. (2004) Time-series fluxes of diatoms in the central and western equatorial Pacific, 1999-2000. In: Poulin, M. (Ed.), Proceedings of 17th International Diatom Symposium 2002, Ottawa, Canada. Biopress, Bristol, England, pp. 271-280.

Onodera, J., and Takahashi, K. 2009. Long-term diatom fluxes in response to oceanographic conditions at Stations AB and SA in the central subarctic Pacific and the Bering Sea, 1990-1998. Deep-Sea Research I, 56, 189-211.

Reynolds, R.W., Rayner, N.A., Smith, T.M., Stokes, D.C., and Wang, W. (2002) An improved in situ and satellite SST analysis for climate. Journal of Climate, 15, 1609-1625. WWW page http://ingrid.ldeo.columbia.edu/SOURCES/.IGOSS/.nmc/.weekly/.

Romero, O.E., Lange, C.B., Fischer, G., Treppke, U.F., and Wefer, G. (1999) Variability in export production documented by downward fluxes and species composition of marine planktonic diatoms: observations from the tropical and equatorial Atlantic. In: Fischer, G., Wefer, G. (Eds.), Use of Proxies in Paleoceanography, Examples from the South Atlantic. Springer Verlag, Berlin, Heidelberg, pp. 365-392.

Romero, O.E., Fischer, G., Lange, C.B., and Wefer, G. (2000) Siliceous phytoplankton of the western equatorial Atlantic: Sediment traps and surface sediments. Deep-Sea Research II, 47, 1939-1959.

Takahashi, K. (1986) Seasonal fluxes of pelagic diatoms in the subarctic Pacific, 1982-1983. DeepSea Research, 33, 1225-1251.

Takahashi, K., and Honjo, S. (1983) Radiolarian skeletons: Size, weight, sinking speed and residence time in tropical pelagic oceans. Deep-Sea Research, 30(5A), 548-568.

Takahashi, K., Kobayashi, F., and Ono, I. (2002) Seasonal fluxes of diatoms in the western equatorial Pacific during the 1999 La Niña conditions. Journal of the Geological Society of Japan, 108, 721-732. [In Japanese with English Abstract]

Takahashi, K., Onodera, J., and Katsurada, Y. submitted. Time-series fluxes of diatoms in the central and western equatorial Pacific, 1999-2002: the relationships between tempo-spatial migrations of the Western Pacific Warm Pool with El Niño-Southern Oscillation and taxonquantitative variations. Submitted to Deep-Sea Research I.

Takano, H. (1990) Diatoms. In: Fukuyo, Y., Takano, H., Chihara, M., and Matsuoka, K., (Eds.), Red tide organisms in Japan - An illustrated taxonomic guide. Uchida Rokakuho, Tokyo, pp. 162331.

Treppke, U.F., Lange, C.B., and Wefer, G., (1996) Vertical fluxes of diatoms and silicoflagellates in the eastern equatorial Atlantic, and their contribution to the sedimentary record. Marine Micropaleontology, 28, 73-96.

Yan, X.-H., Ho, C-R., Zheng, Q., and Klemas, V. (1992) Temperature and size variation of the Western Pacific Warm Pool. Science, 258, 1643-1645. 
Diatom sinking fluxes in the western and central Equatorial Pacific1999-2002

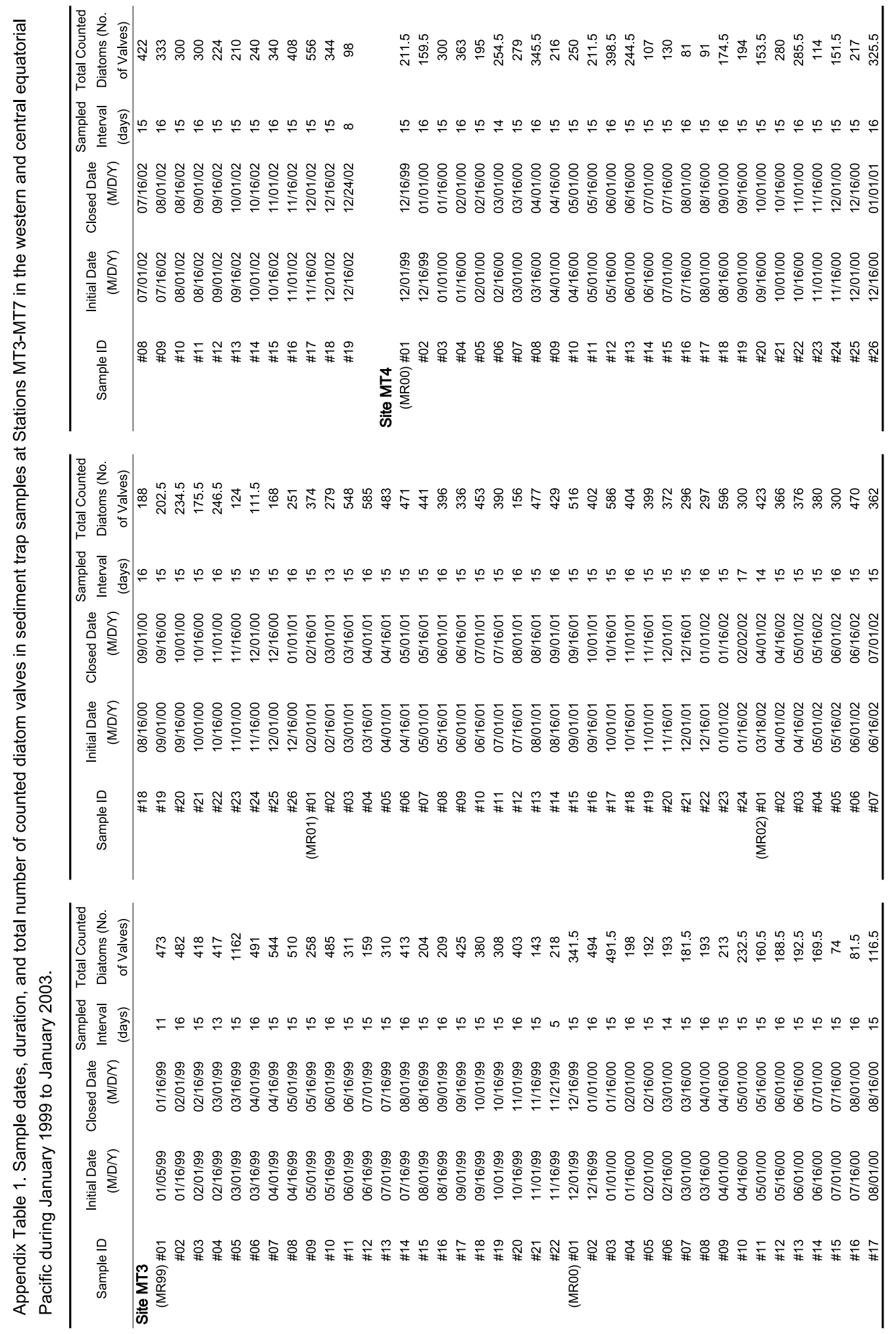




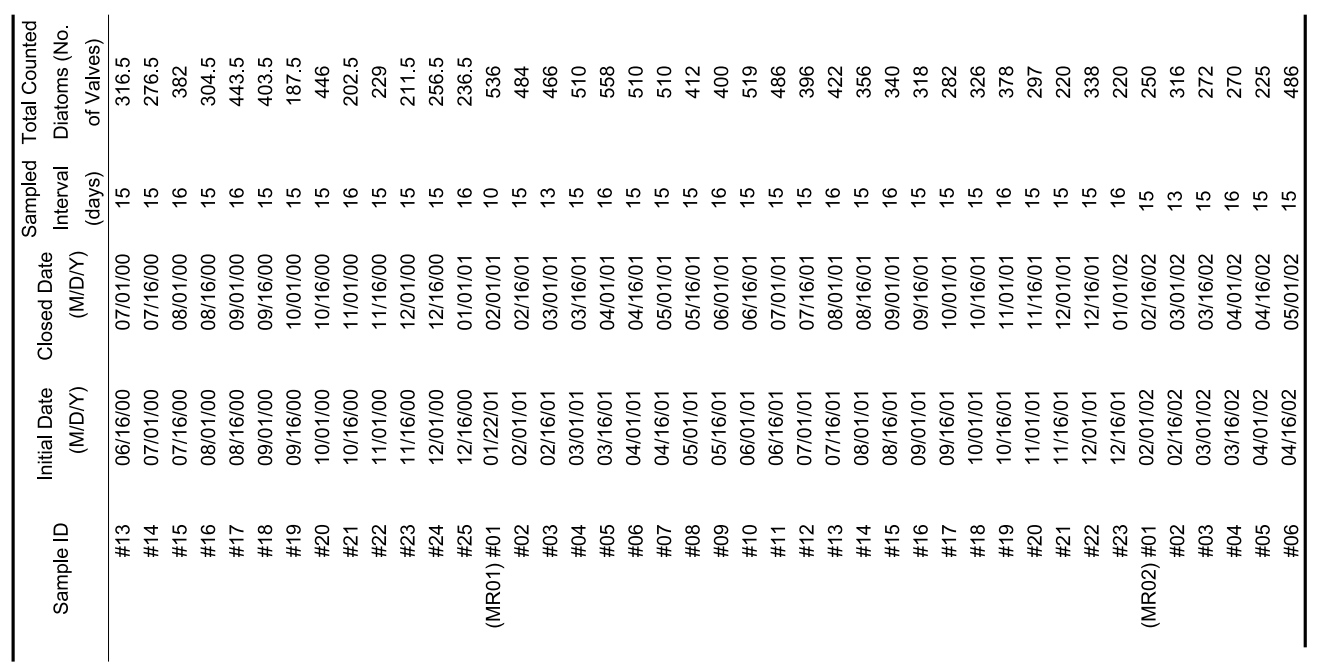

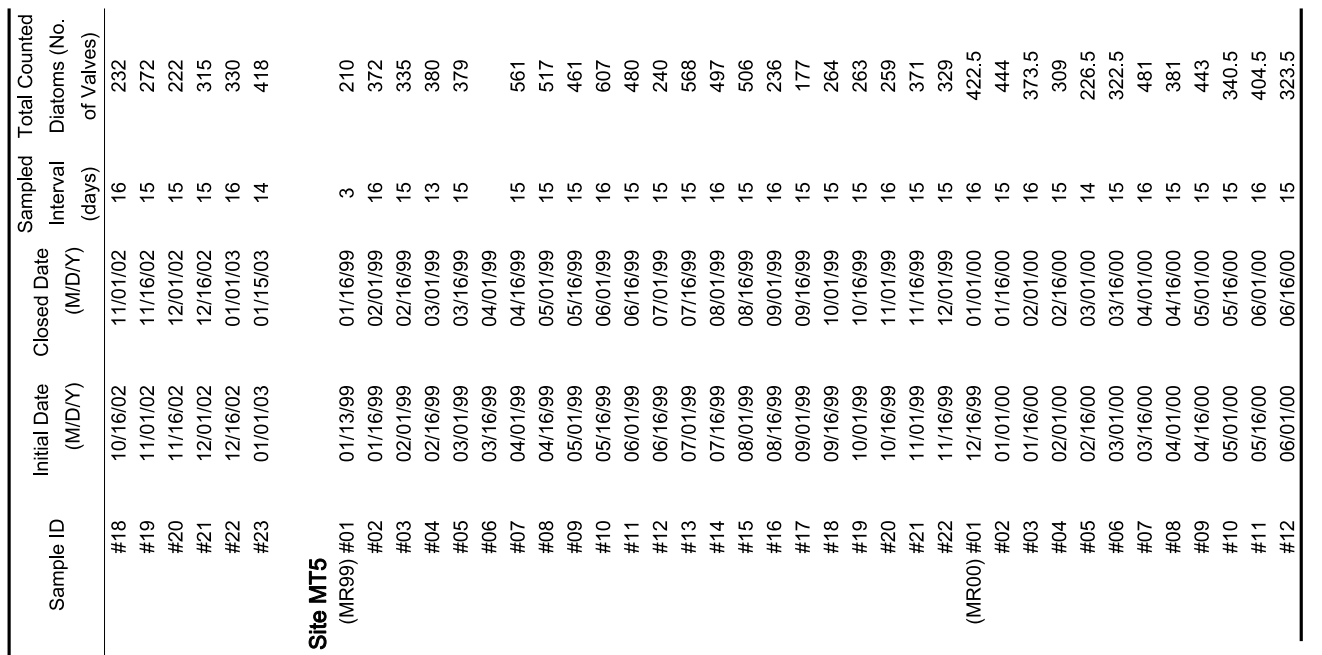

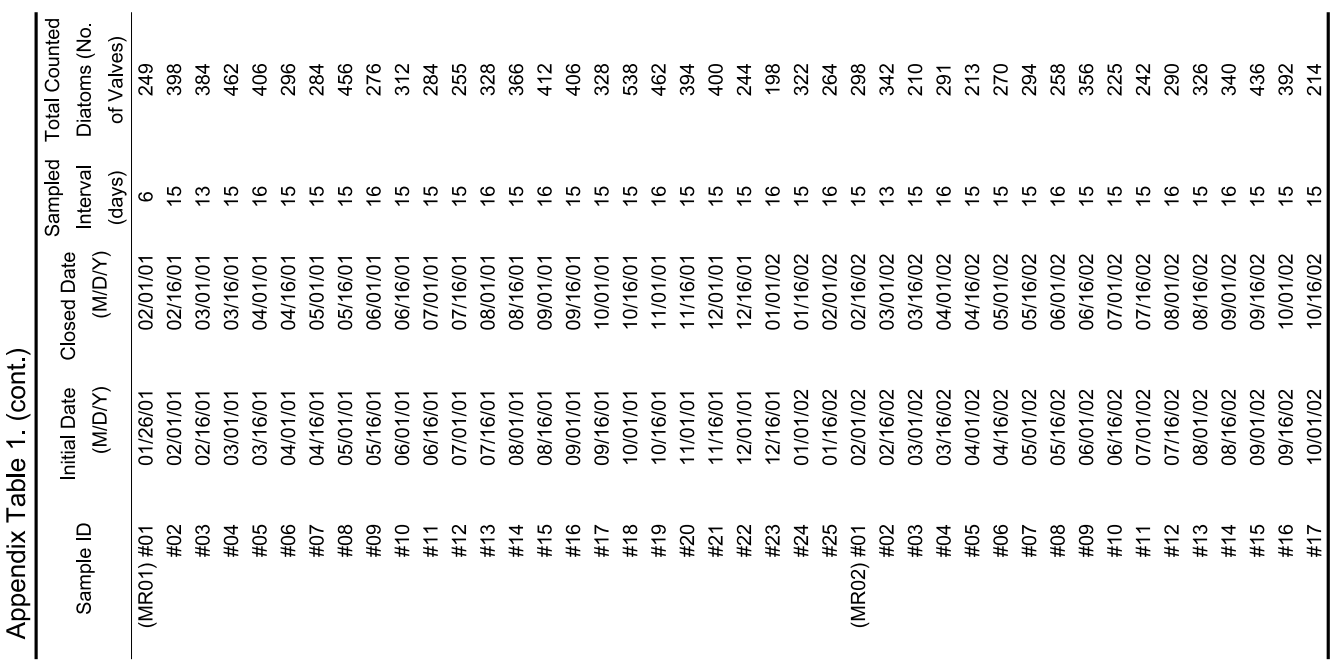


Diatom sinking fluxes in the western and central Equatorial Pacific1999-2002

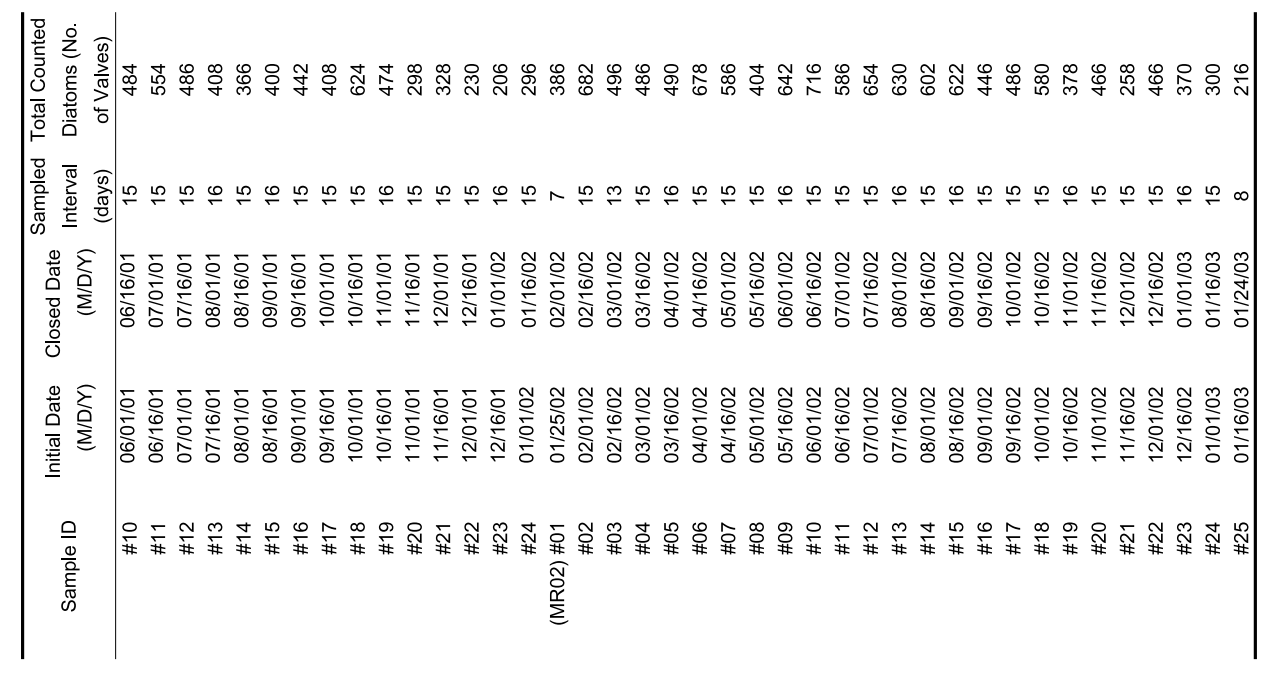

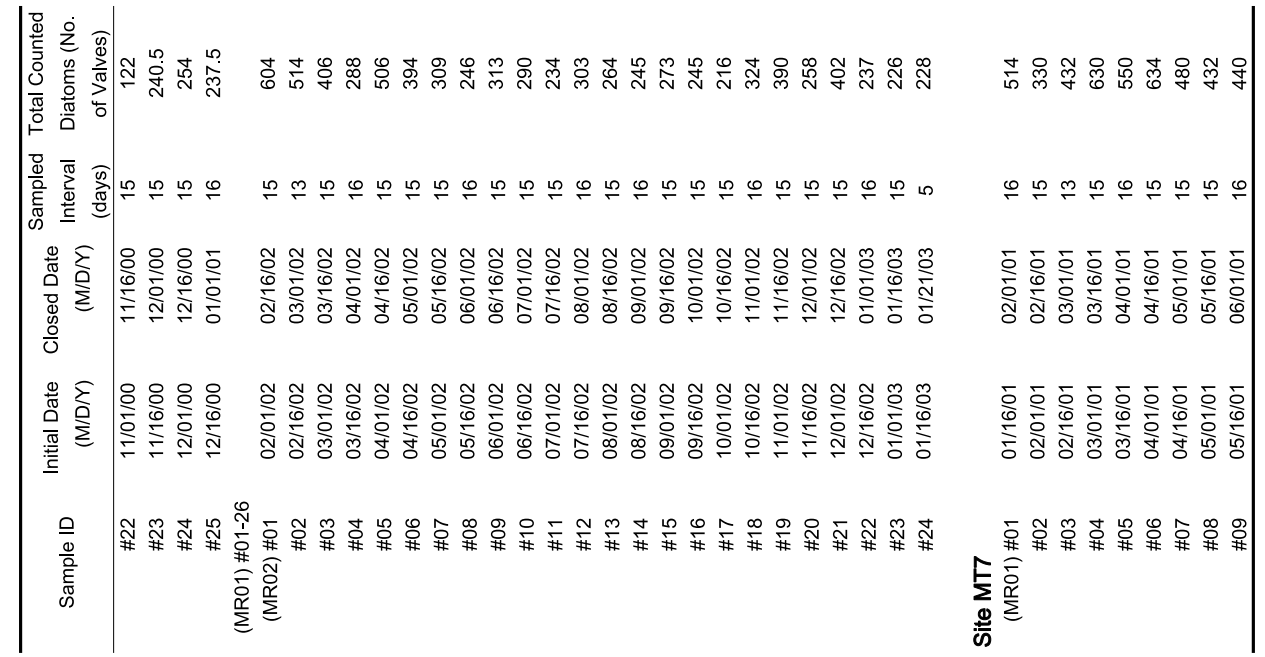

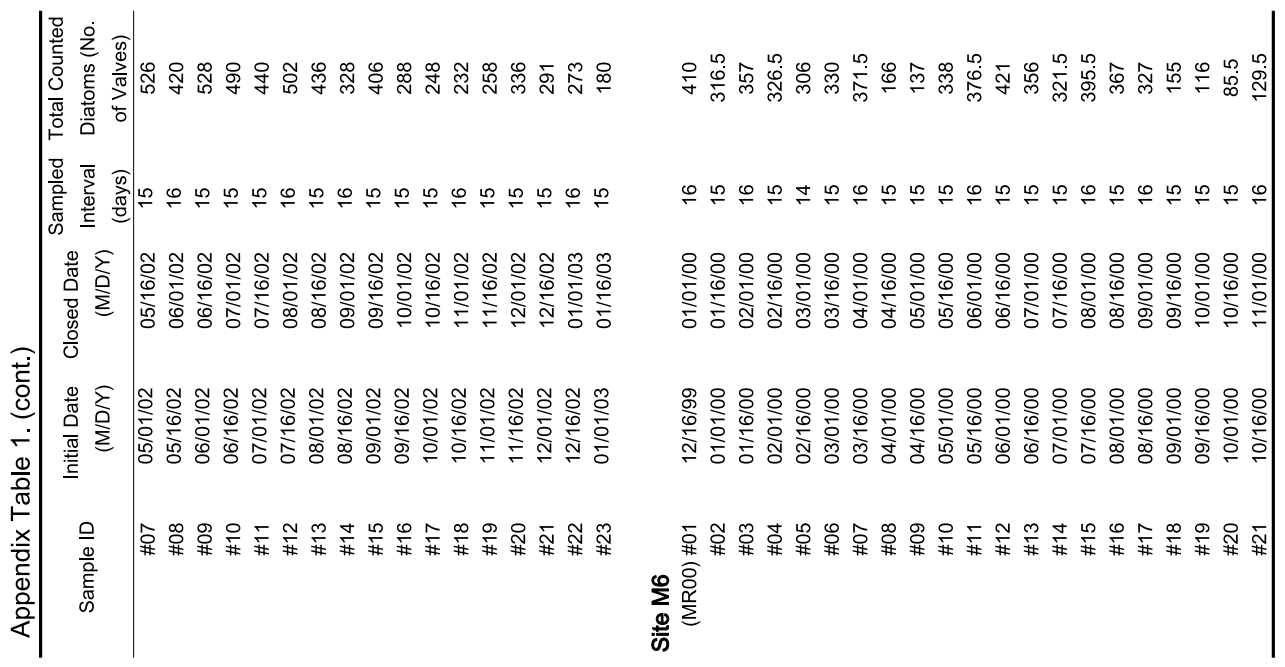




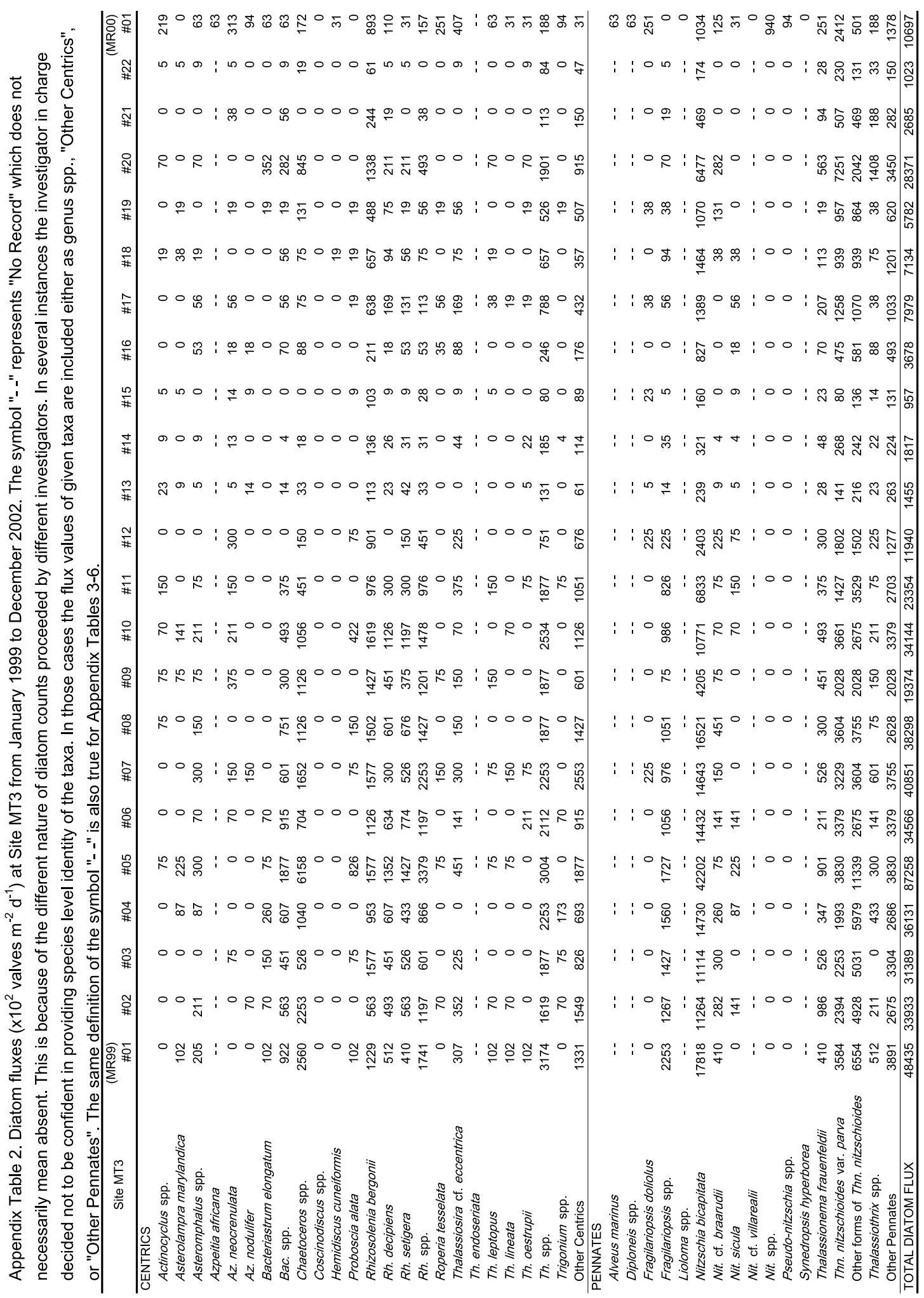




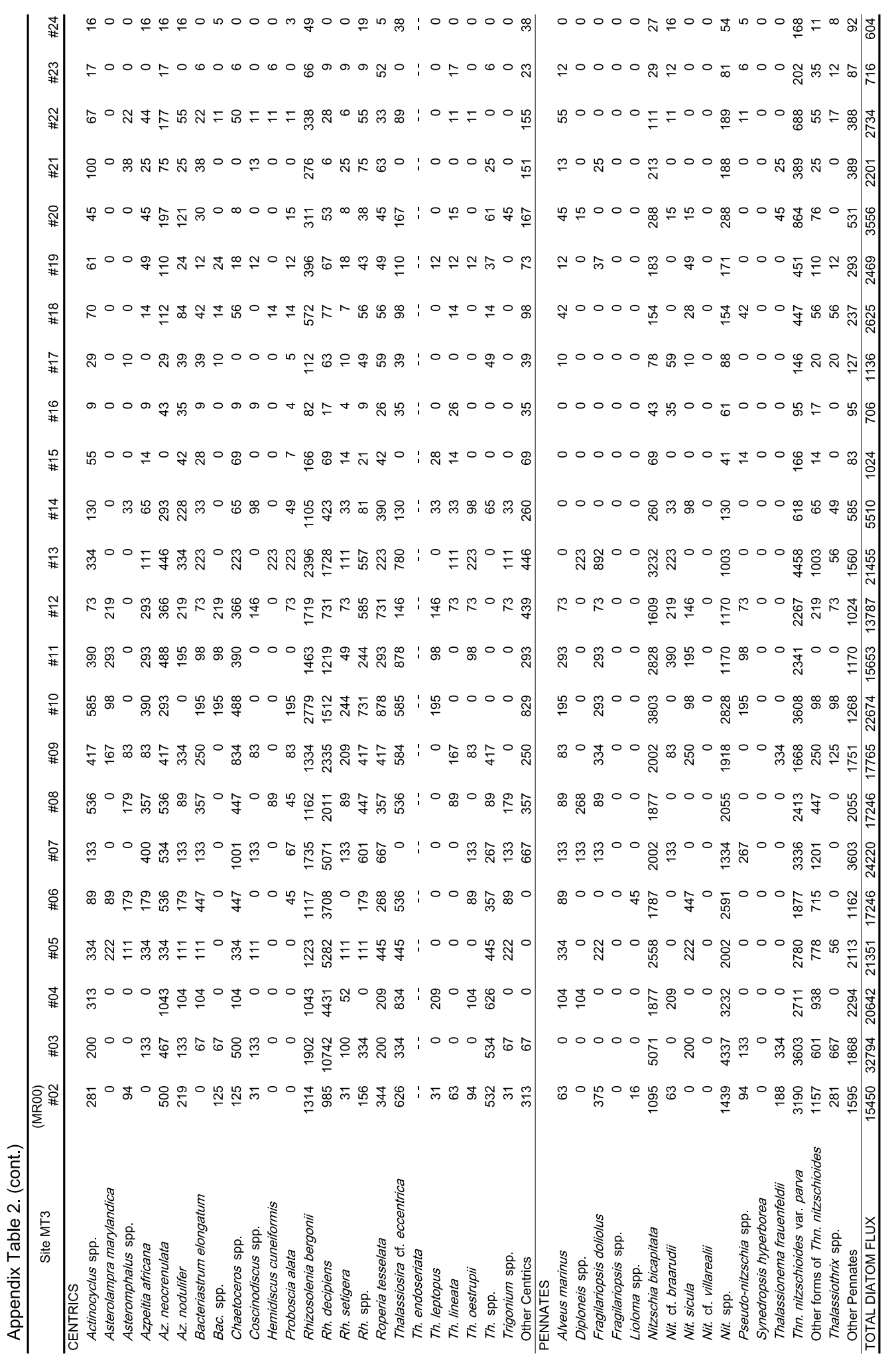




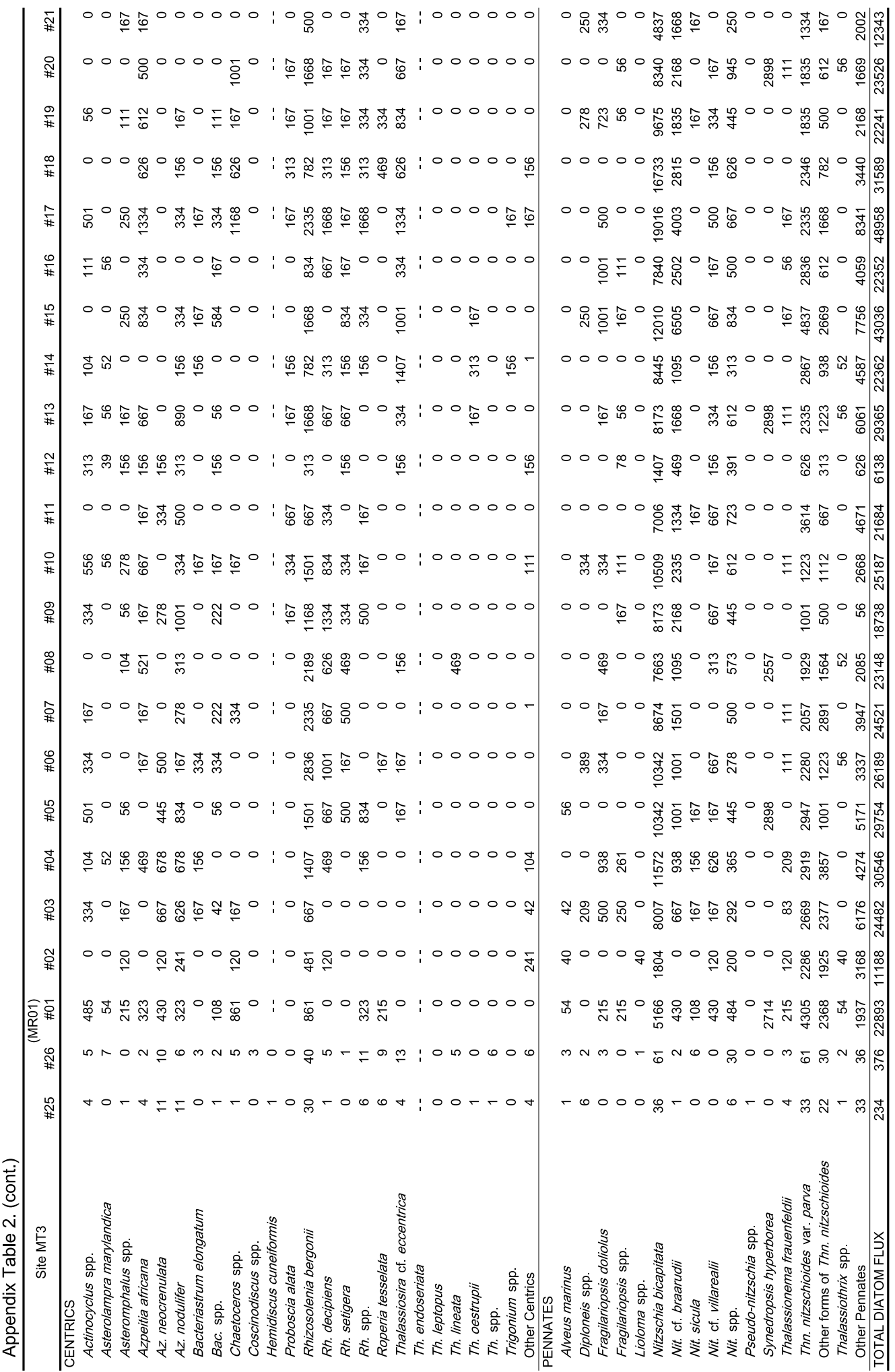




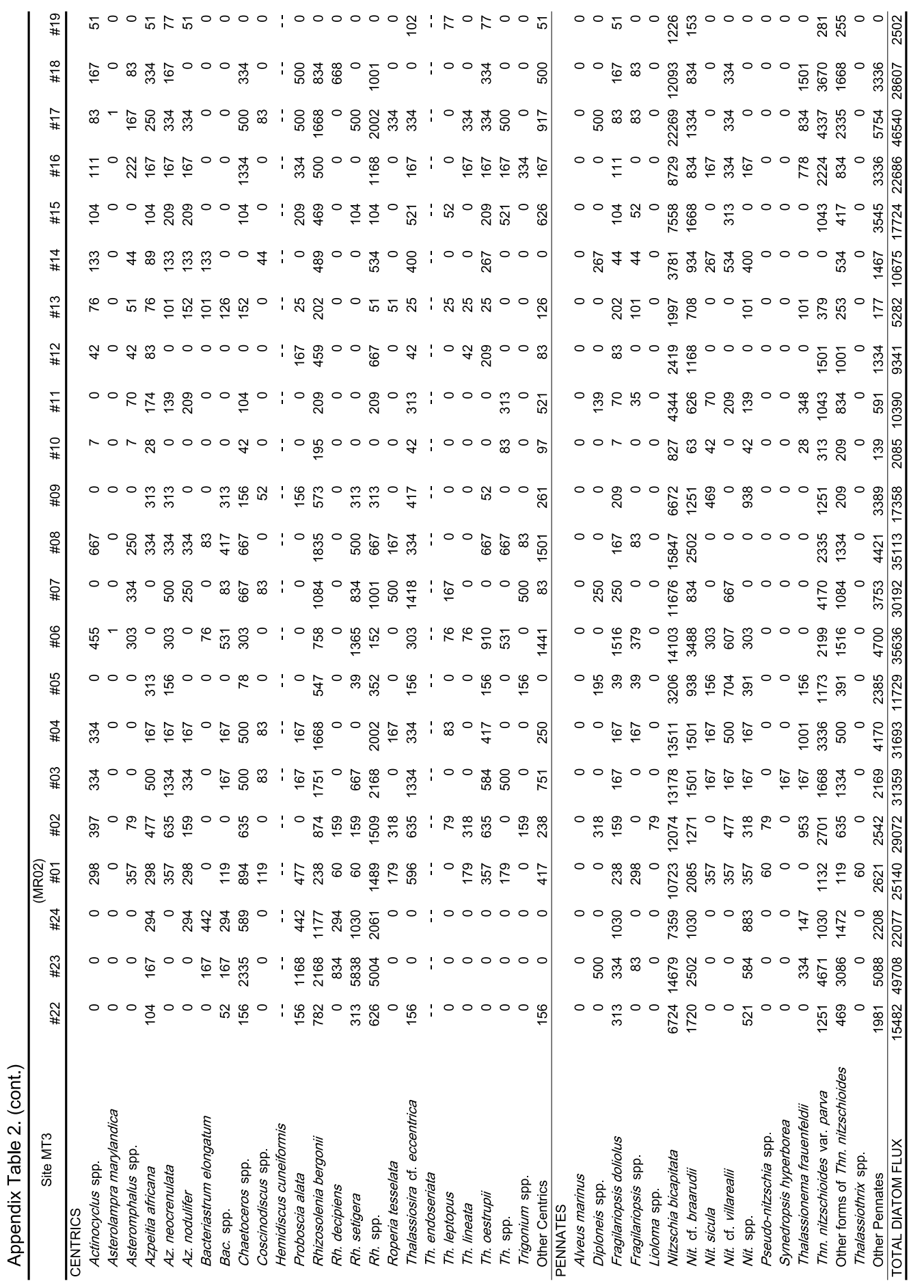




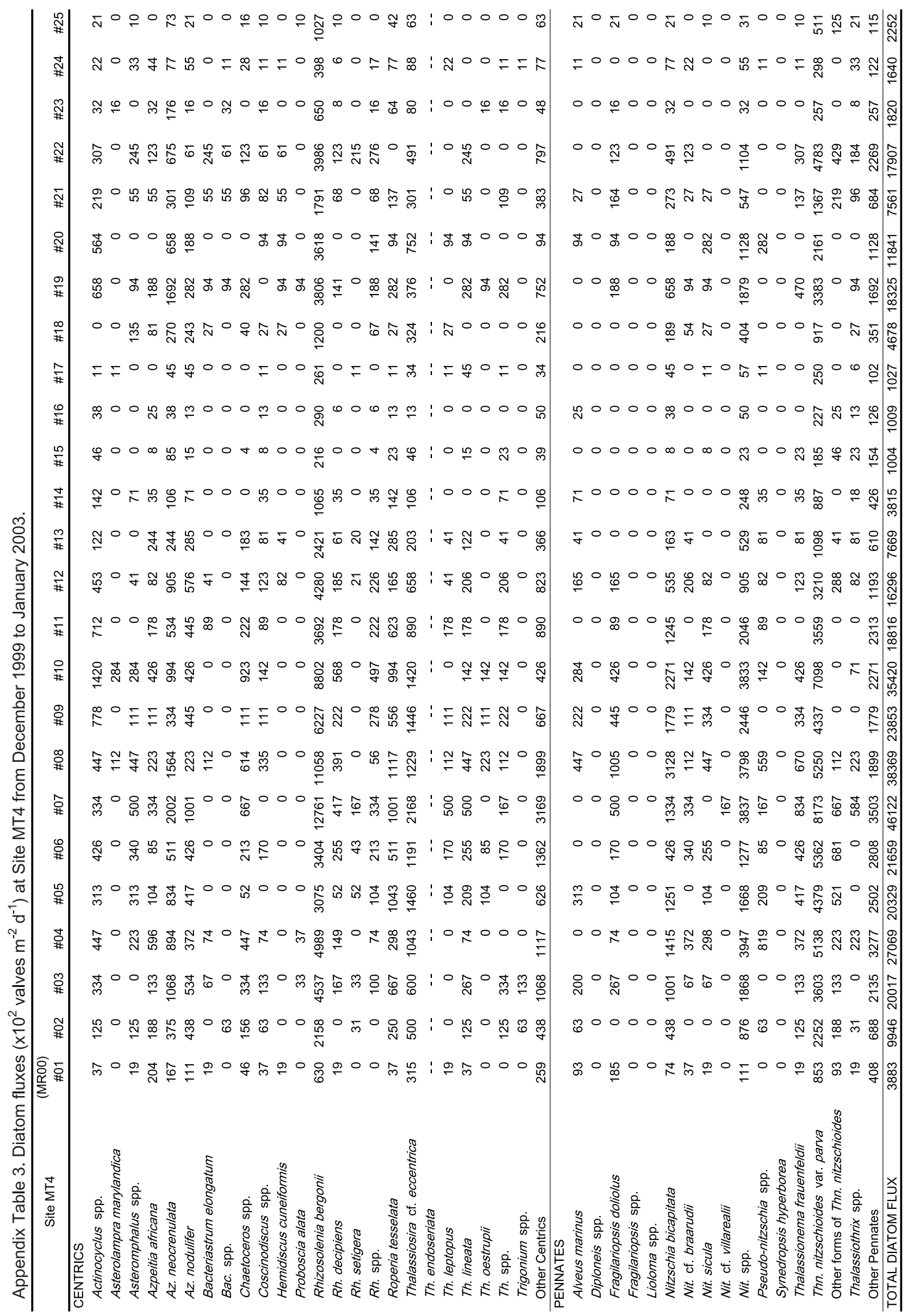




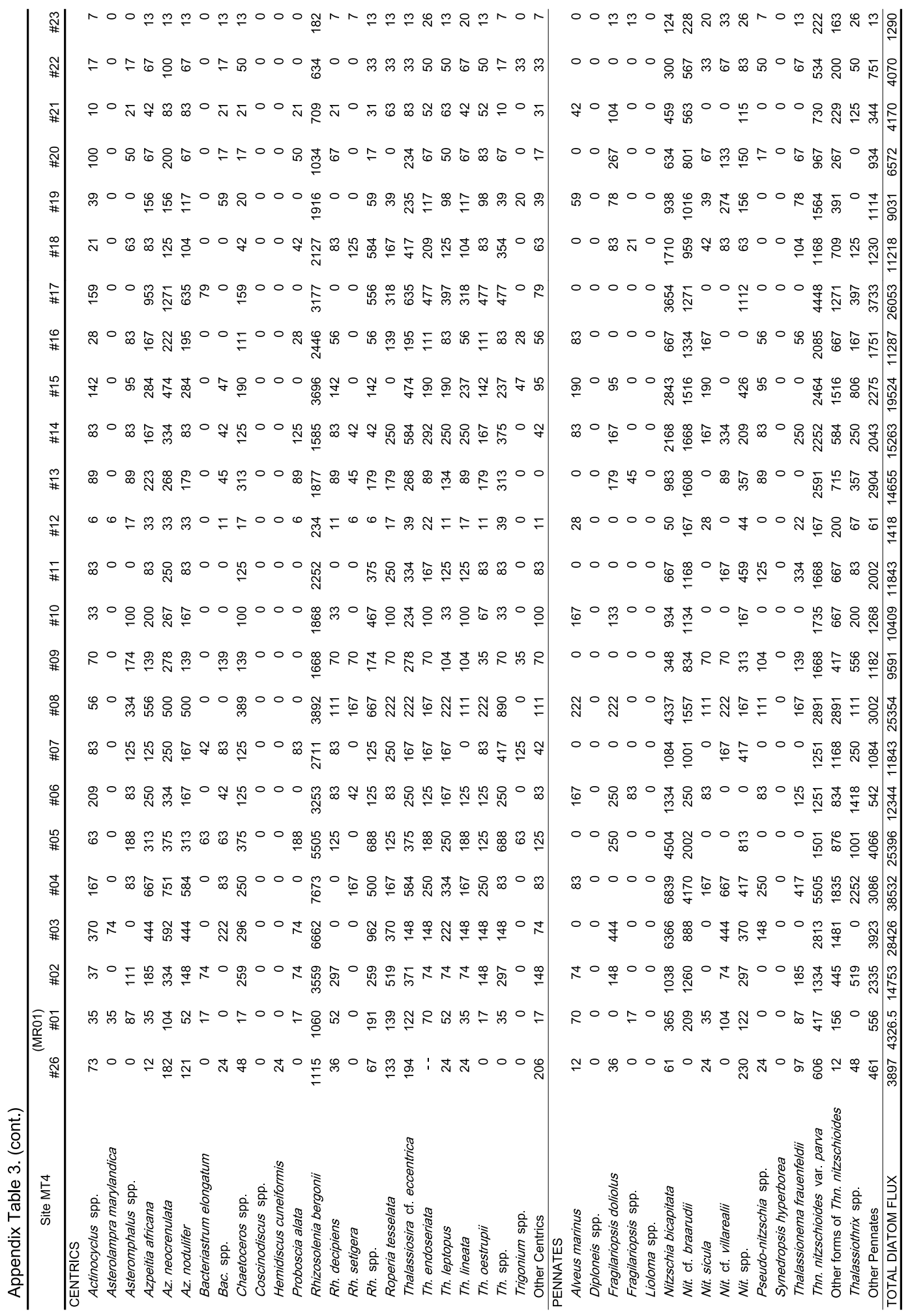




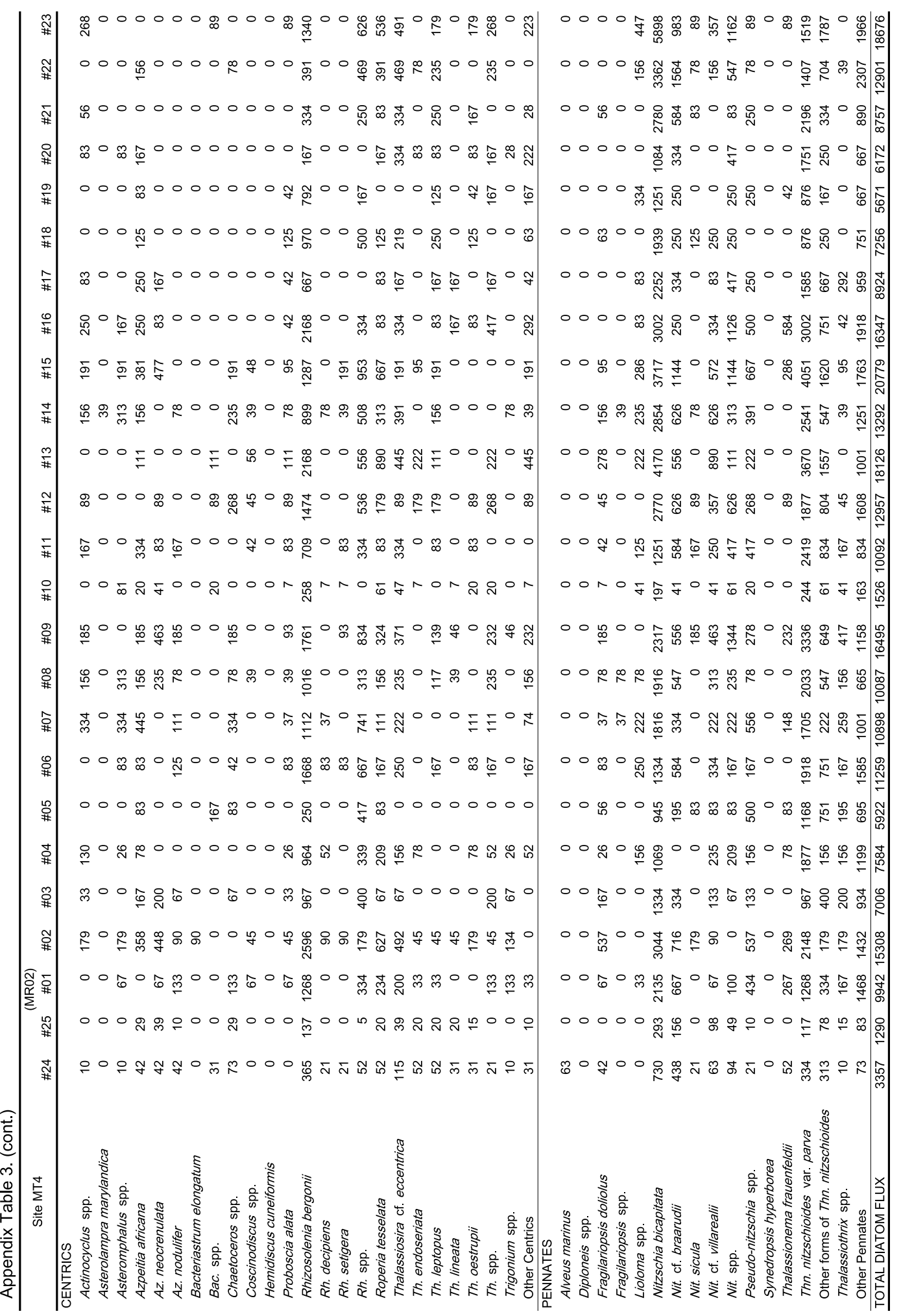




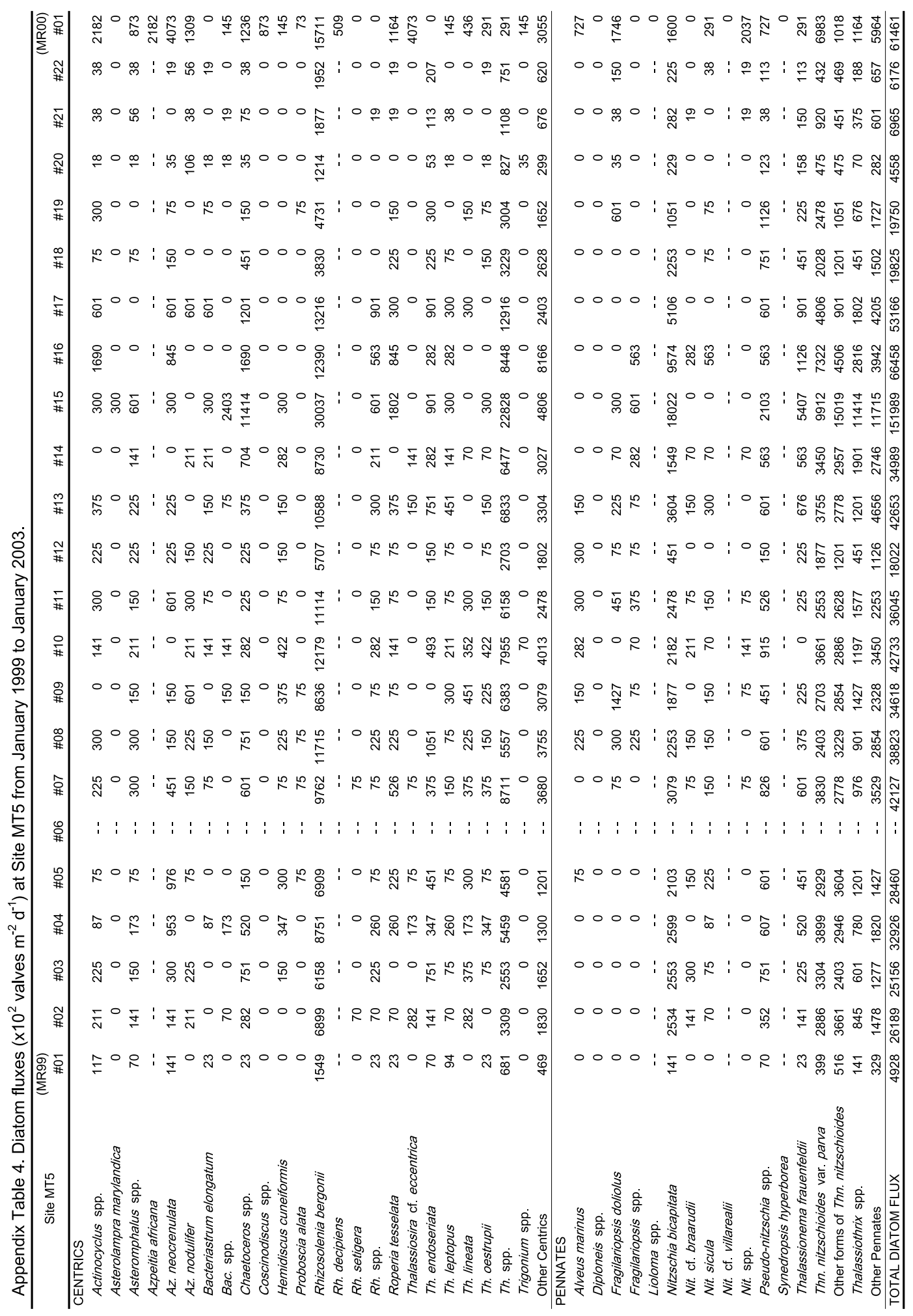




\begin{tabular}{|c|c|c|}
\hline$\approx$ & 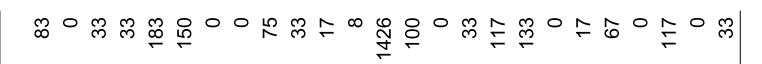 & 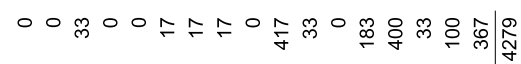 \\
\hline$\cong$ & 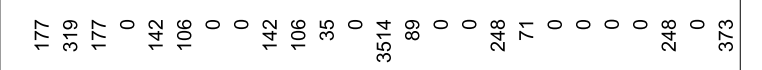 & 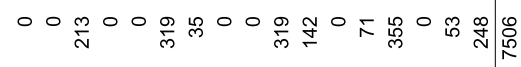 \\
\hline 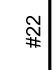 & 员O & 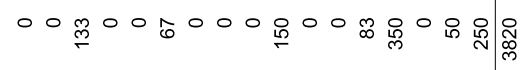 \\
\hline$\cong$ & 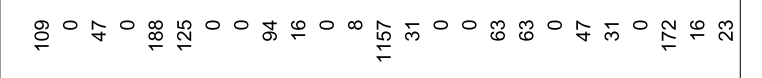 & 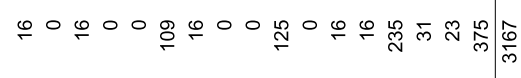 \\
\hline 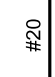 & 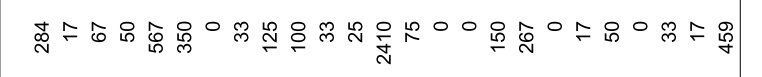 & $\hat{\sigma}^{\circ} \stackrel{\circ}{\digamma} \circ \stackrel{\circ}{\circ} \circ$ 品 \\
\hline 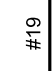 & N & 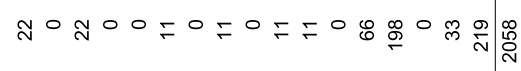 \\
\hline$\stackrel{\infty}{\#}$ & 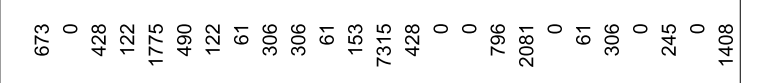 & 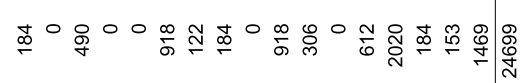 \\
\hline 笋 & 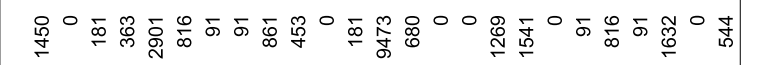 & 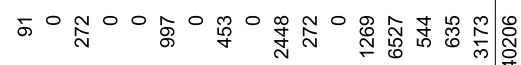 \\
\hline 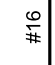 & 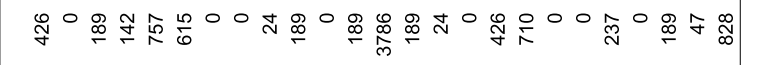 & 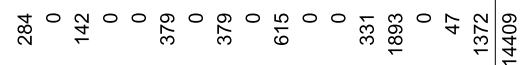 \\
\hline$\stackrel{0}{ \pm}$ & 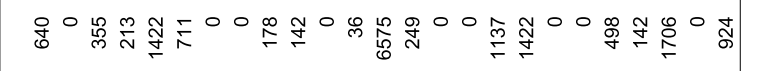 & 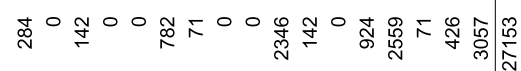 \\
\hline$\underset{I t}{t}$ & 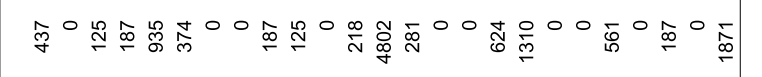 & 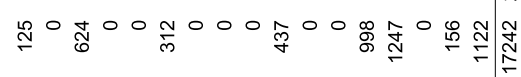 \\
\hline$\stackrel{m}{\#}$ & 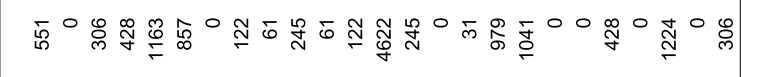 & 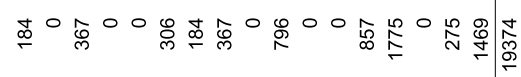 \\
\hline$\stackrel{\sim}{\sharp}$ & 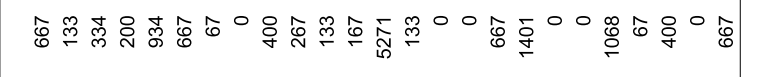 & 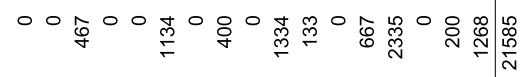 \\
\hline 市 & 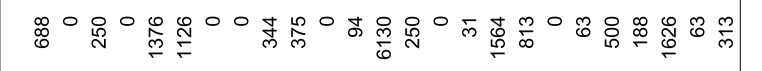 & 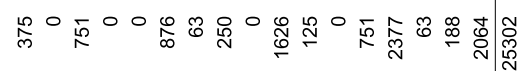 \\
\hline 잎 & 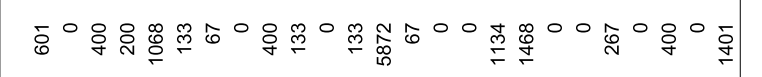 & 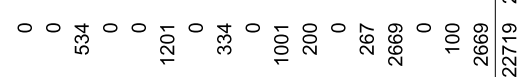 \\
\hline 䁬 & 容 & 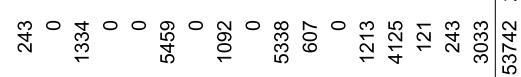 \\
\hline 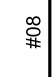 & 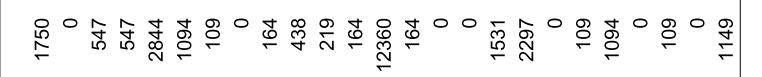 & 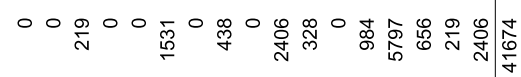 \\
\hline ঐ & 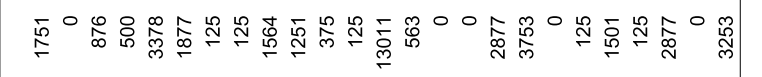 & 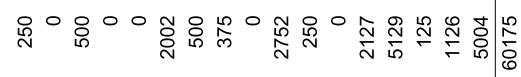 \\
\hline$\stackrel{8}{\sharp}$ & 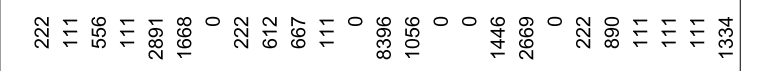 & 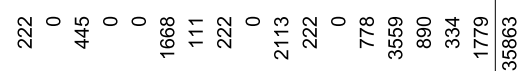 \\
\hline 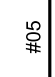 & 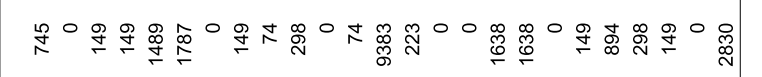 & 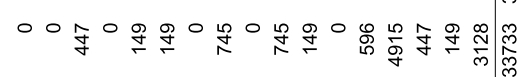 \\
\hline $\begin{array}{c}\ddagger \\
⿱\end{array}$ & 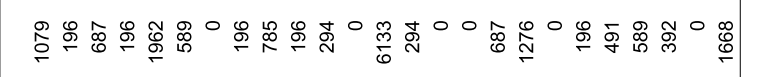 & 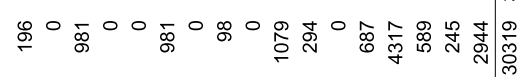 \\
\hline 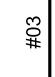 & 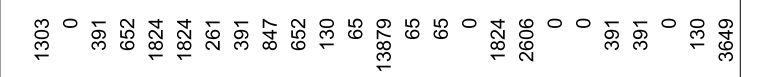 & 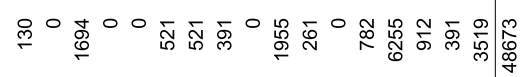 \\
\hline$\tilde{z}$ & 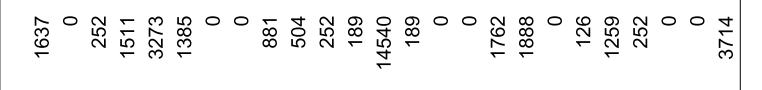 & 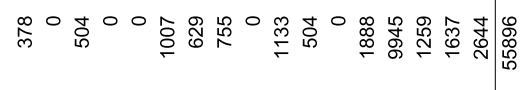 \\
\hline & 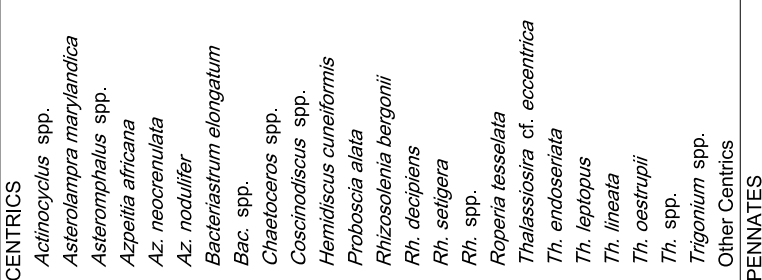 & 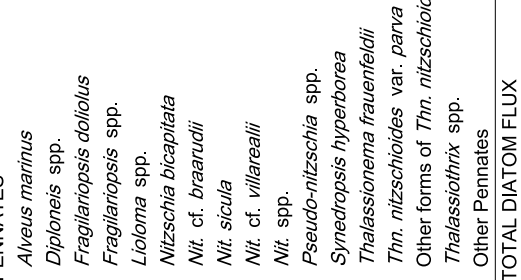 \\
\hline
\end{tabular}




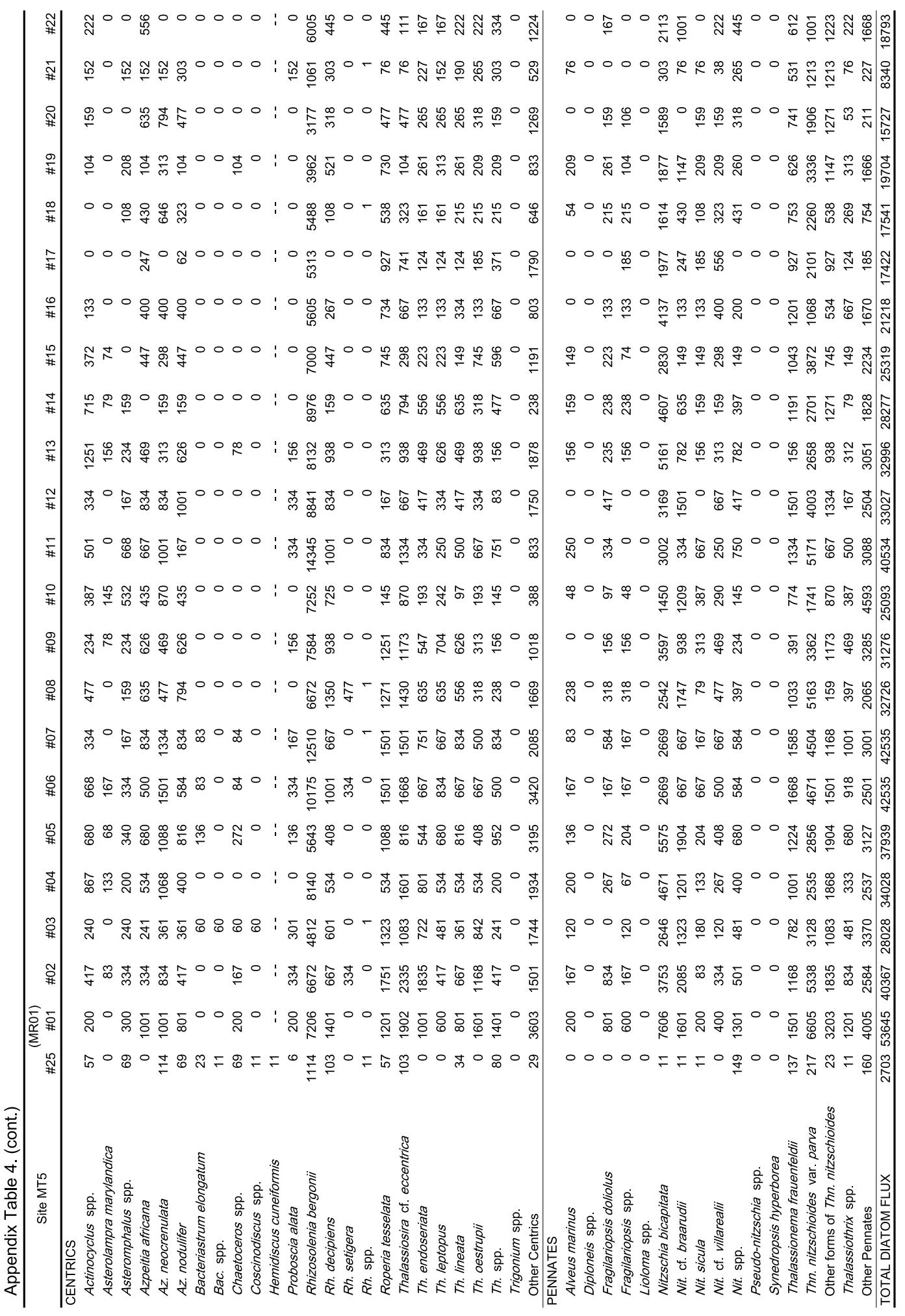




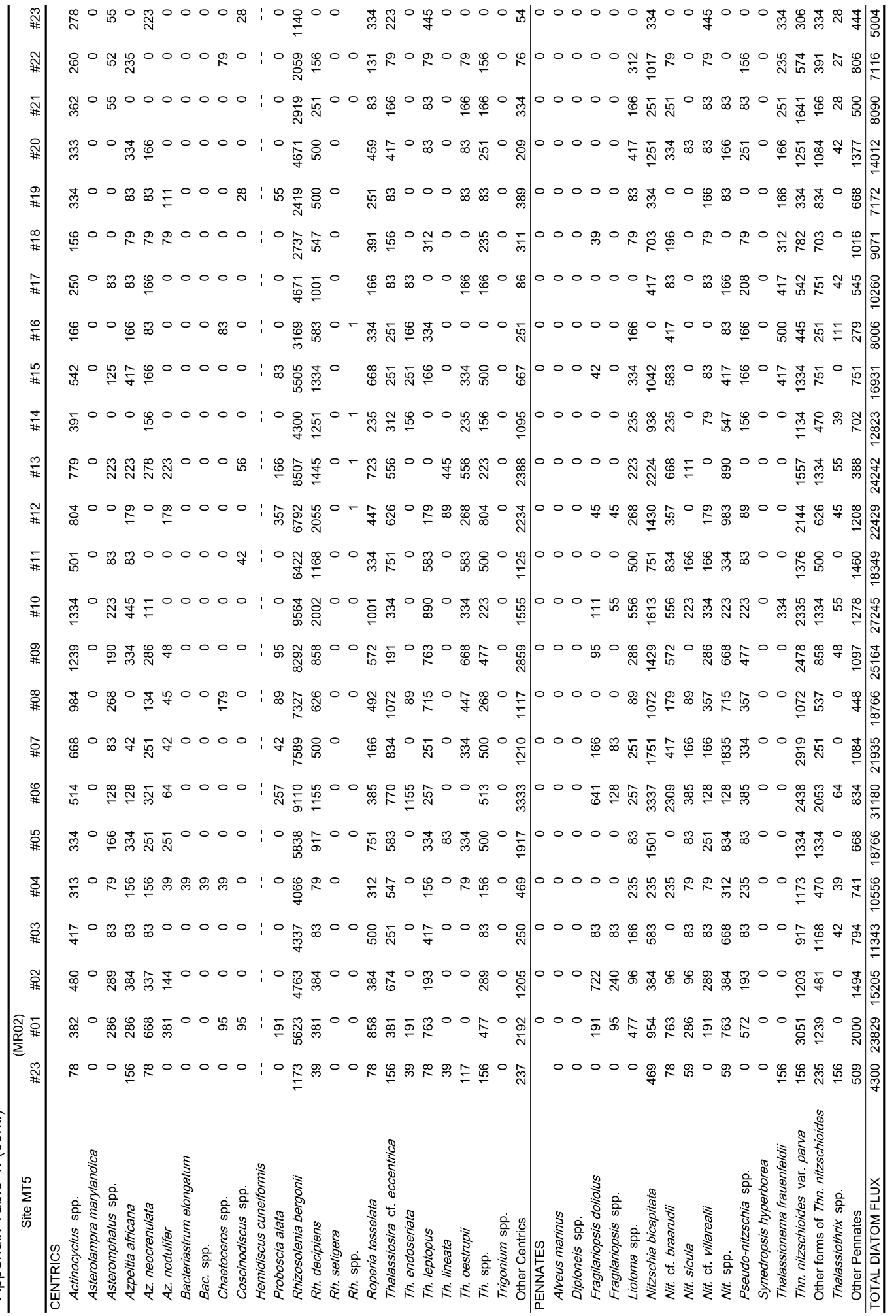




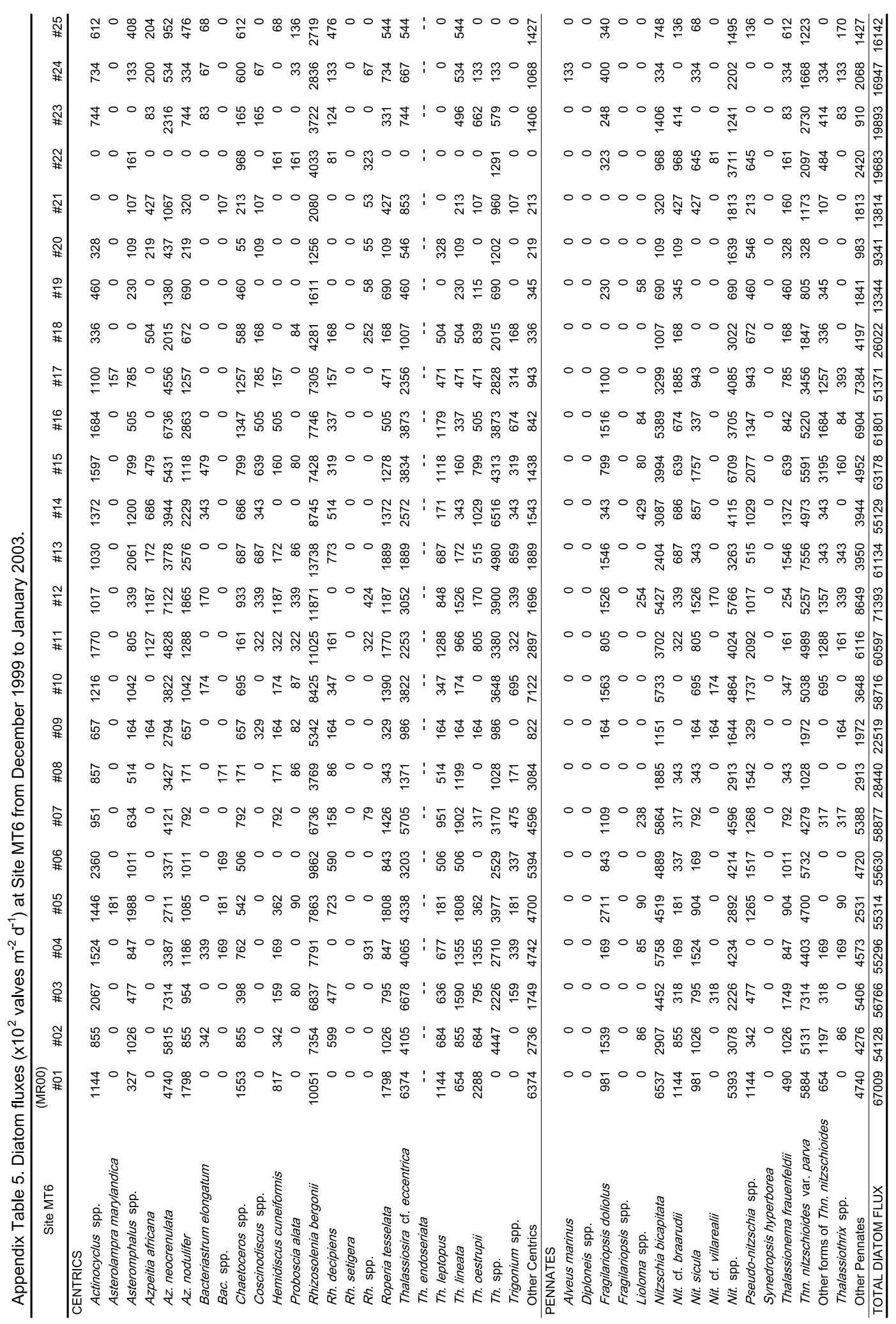




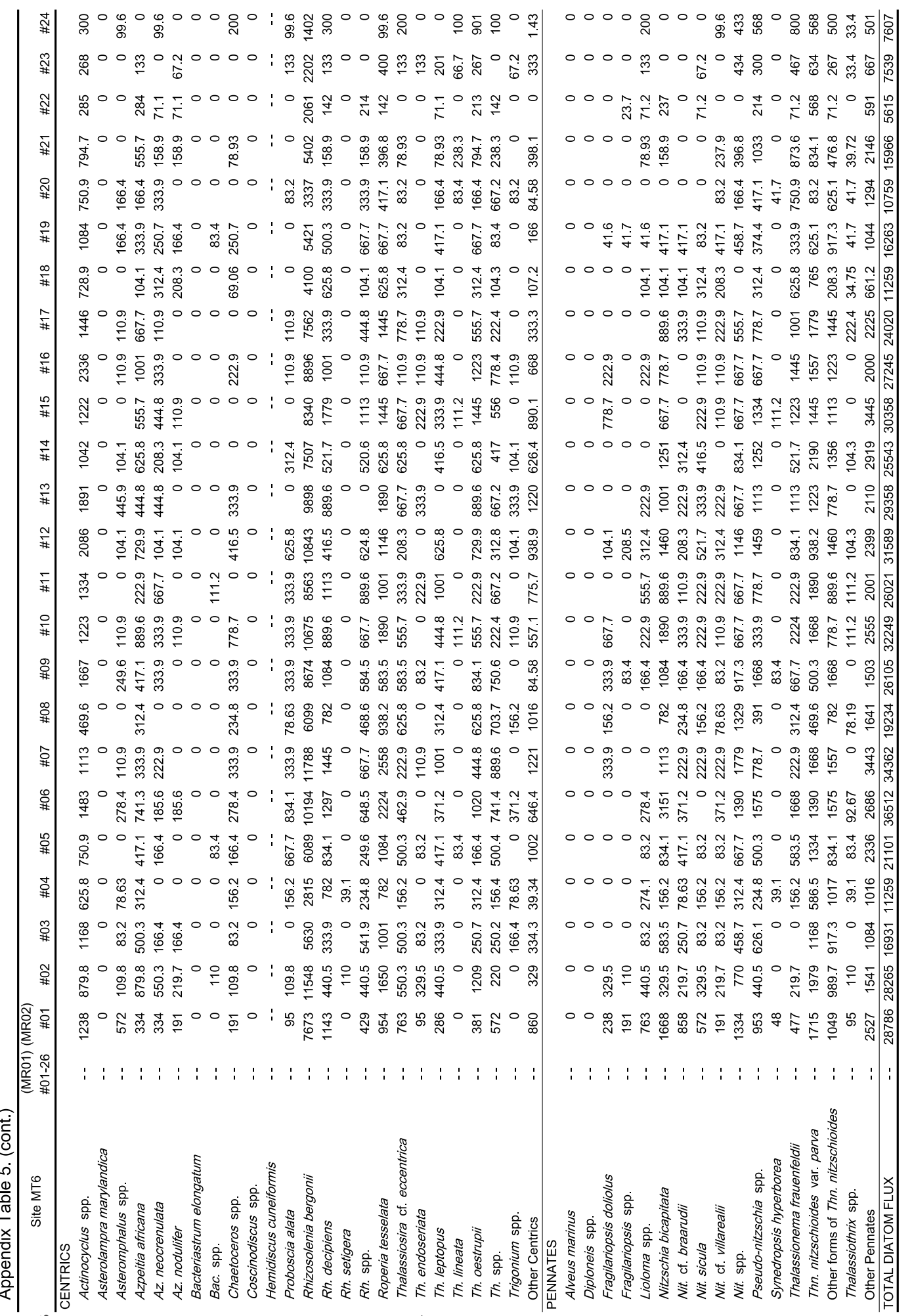




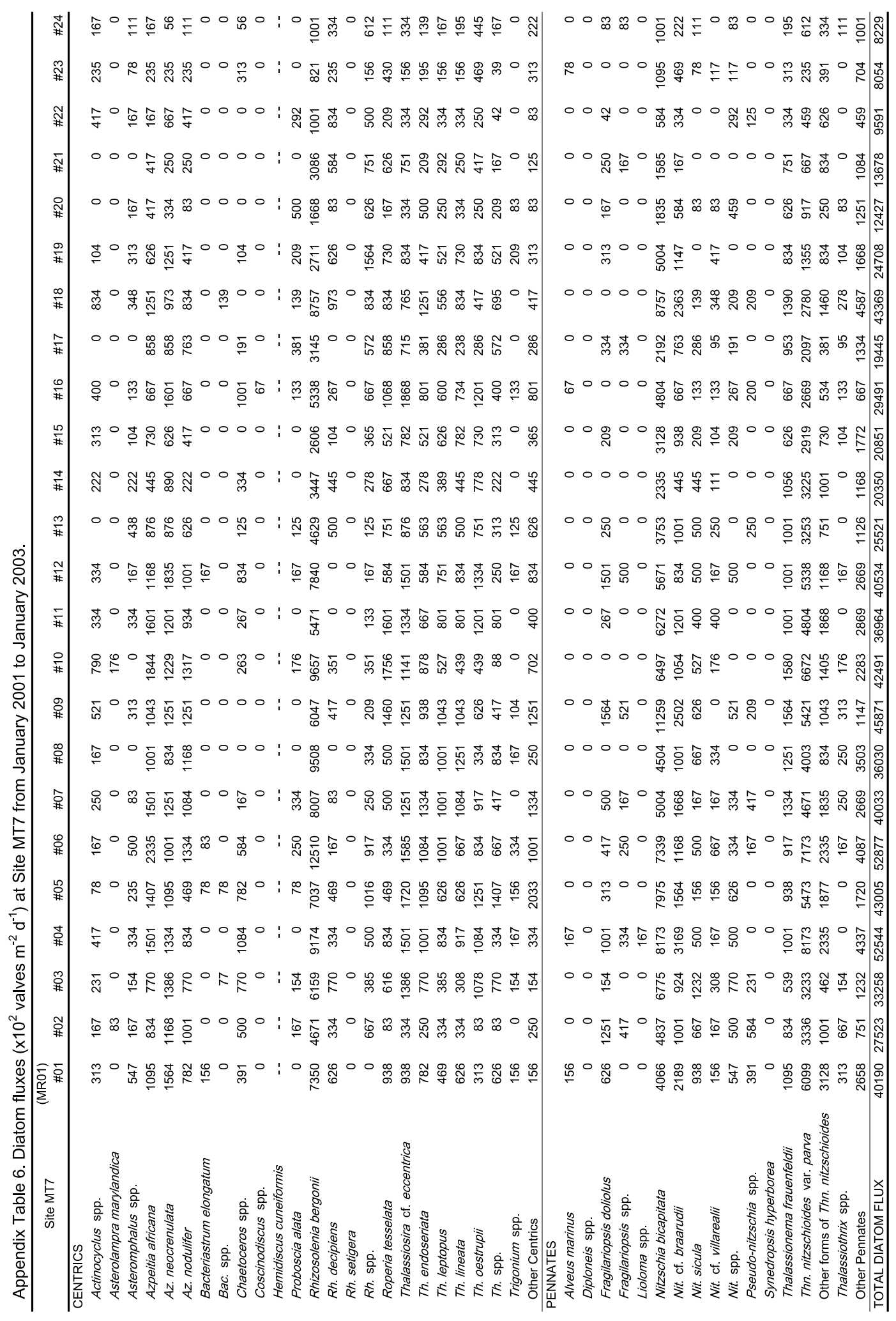




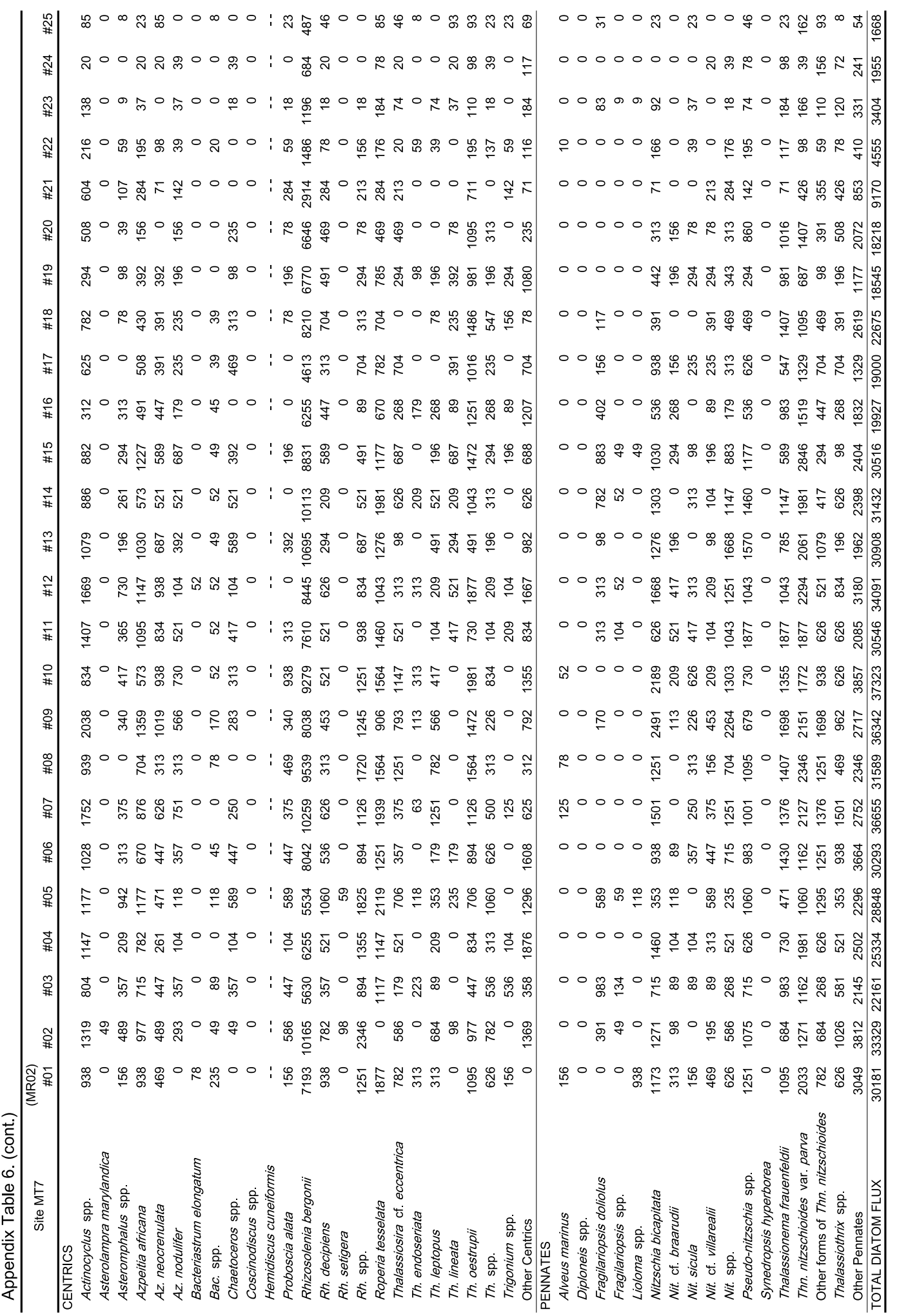

